\title{
Components of the Pseudomonas syringae Type III Secretion System Can Suppress and May Elicit Plant Innate Immunity
}

\author{
Hye-Sook Oh, Duck Hwan Park, and Alan Collmer \\ Department of Plant Pathology and Plant-Microbe Biology, Cornell University, Ithaca, NY 14853, U.S.A.
}

Submitted 10 November 2009. Accepted 11 January 2010.

\begin{abstract}
The type III secretion system (T3SS) of Pseudomonas syringae translocates into plant cells multiple effectors that suppress pathogen-associated molecular pattern (PAMP)triggered immunity (PTI). P. syringae pv. tomato DC3000 no longer delivers the T3SS translocation reporter AvrPto-Cya in Nicotiana benthamiana leaf tissue in which PTI was induced by prior inoculation with $P$. fluorescens(pLN18). Cosmid pLN18 expresses the T3SS system of $P$. syringae pv. syringae 61 but lacks the hopA $1_{P s y 61}$ effector gene. $P$. fluorescens (pLN18) expressing $\mathrm{HrpH}_{\mathrm{PtoDC} 3000}$

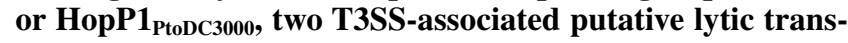
glycosylases, suppresses PTI, based on multiple assays involving DC3000 challenge inoculum (AvrPto-Cya translocation, hypersensitive response elicitation, and colony development in planta) or on plant responses (vascular dye uptake or callose deposition). Analysis of additional mutations in pHIR11 derivatives revealed that the pLN18encoded T3SS elicits a higher level of reactive oxygen species (ROS) than does P. fluorescens without a T3SS, that enhanced ROS production is dependent on the HrpK1 translocator, and that HopA1 $1_{\text {Psy61 }}$ suppresses ROS elicitation attributable to both the $P$. fluorescens PAMPs and the presence of a functional T3SS.
\end{abstract}

Pseudomonas syringae is a plant pathogen that colonizes the intercellular spaces in leaves and other aerial organs and causes diseases in a wide variety of crops. $P$. syringae defeats plant innate immunity by injecting effector proteins into host cells via the type III secretion system (T3SS). A current model for $P$. syringae-plant interactions holds that bacterial pathogen (or microbe)-associated molecular patterns (PAMPs or MAMPs), such as flagellin, lipopolysaccharide, peptidoglycan, and elongation factor TU, elicit PAMP-triggered immunity (PTI) in plant cells, that an essential function of type III effectors is to suppress PTI, and that the activities of effectors inside plant cells can be recognized by $\mathrm{R}$ proteins in a second level of defense known as effectortriggered immunity (ETI) (Boller and Felix 2009; Jones and Dangl 2006). ETI commonly results in a localized, rapid, programmed cell death known as the hypersensitive response (HR). In a coevolutionary arms race with plants, pathogens

Hye-Sook Oh and Duck Hwan Park contributed equally to this study.

Corresponding author: A. Collmer; E-mail: arc2@cornell.edu; Telephone: +1.607.255.7843; Fax: +1.607.255.4471.

* The $\boldsymbol{e}$-Xtra logo stands for "electronic extra" and indicates that a supplementary figure is available online. defeat ETI by mutating betraying effector genes or by injecting other effectors that suppress ETI (but which may fall under surveillance of new $\mathrm{R}$ proteins). According to this model, the outcome of an infection is determined largely by interactions of complex repertoires of pathogen effectors and plant $\mathrm{R}$ proteins, with the role of the T3SS being limited to the injection of effectors. That is, the T3SS machinery itself has no role in eliciting, suppressing, or being a target of plant defenses.

Progress has been made in understanding mechanisms of PAMP perception, in identifying global changes in gene expression, and in developing several assays for physiological and transcriptional markers (especially in Arabidopsis) for the PTI state (Boller and Felix 2009). PTI is readily induced experimentally by infiltrating high levels of a T3SS-deficient pathogen or a nonpathogen into plant leaf tissue; within $6 \mathrm{~h}$, the infiltrated tissue no longer supports the growth of a virulent pathogen or HR elicitation by an avirulent pathogen (Klement et al. 2003; Oh and Collmer 2005). Other physiological markers for PTI include the formation of callose deposits (Hauck et al. 2003), reduced uptake of vascular dyes into minor veins (Oh and Collmer 2005), and the generation of reactive oxygen species (ROS) (Chinchilla et al. 2007; Torres et al. 2006). However, the changes in PTI-protected tissue that are responsible for this immunity and the corresponding basis for bacterial failure await elucidation.

Two model systems have proven particularly useful in studying the $P$. syringae T3SS and its effectors. The first is the reference strain Pseudomonas syringae pv. tomato DC3000, a pathogen of Arabidopsis and tomato whose genome sequence is continuously curated and whose type III effector repertoire has been comprehensively identified and largely disassembled through the construction of deletion polymutants (Kvitko et al. 2009; Lindeberg et al. 2006). The second model system involves cosmid pHIR11, which contains a functional cluster of hrp/hrc (HR and pathogenicity or conserved) T3SS genes that were cloned from the bean pathogen $P$. syringae pv. syringae 61 and enable nonpathogens like P. fluorescens and Escherichia coli to elicit the HR in tobacco (Huang et al. 1988). The $P$. syringae genomic region cloned in pHIR11 also includes genes encoding the HopA1 $1_{\text {Psy61 }}$ effector and its chaperone (Alfano et al. 1997; van Dijk et al. 2002). Nonpathogens carrying pHIR11 elicit the $\mathrm{HR}$ in tobacco because HopA1 $1_{\mathrm{Psy} 61}$ acts as an avirulence determinant when injected into tobacco cells (Alfano et al. 1997). Importantly, $P$. fluorescens carrying derivatives of cosmid pHIR11 and its functional cluster of $P$. syringae pv. syringae $61 \mathrm{hrp} / \mathrm{hrc}$ genes enables individually expressed effectors and other substrates of the T3SS pathway to produce strong plant interaction phenotypes that are otherwise masked by redundancy when the 
A
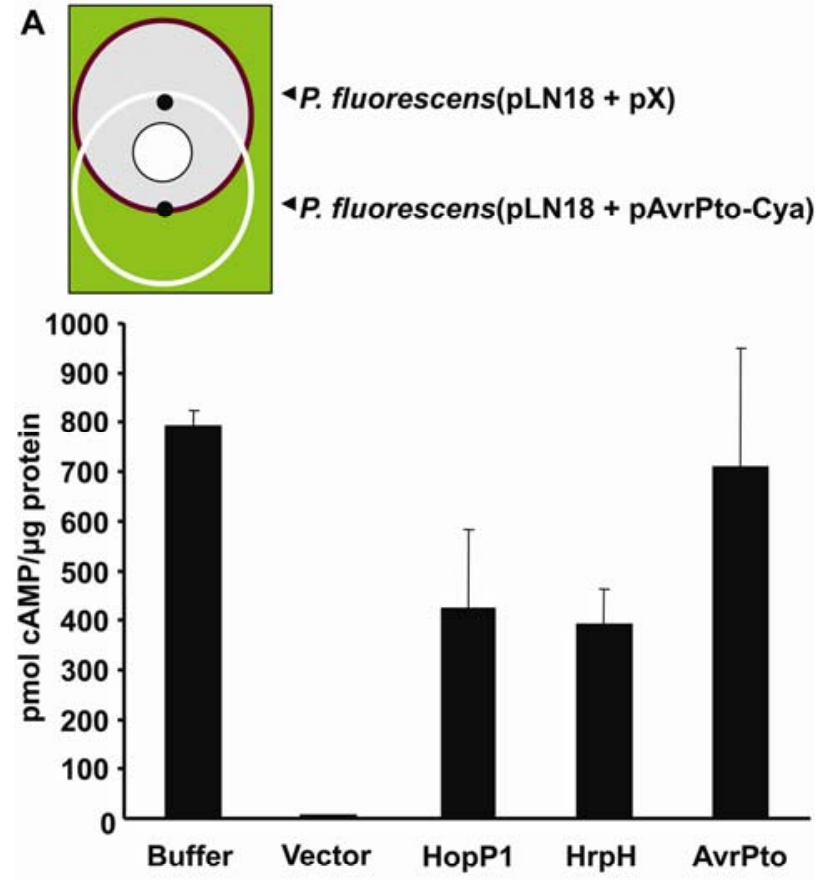

B
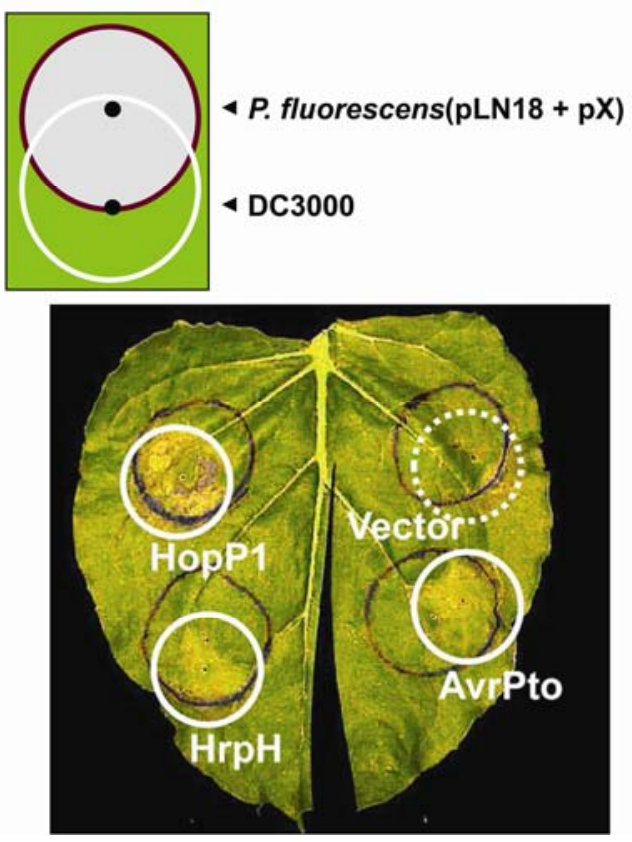

Fig. 1. Pathogen-associated molecular pattern-triggered immunity (PTI) blocks type III secretion system (T3SS) effector translocation by challenge inoculated bacteria, but this defense response can be suppressed if the inducing bacteria deliver $\mathrm{HopP}_{\mathrm{PtoDC} 3000}, \mathrm{HrpH}_{\mathrm{PtoDC} 3000}$, or AvrPto (positive control) via the T3SS. A, As depicted in the diagram, Pseudomonas fluorescens( $\mathrm{pLN} 18)$ strains carrying a second plasmid (pX) expressing $\mathrm{HrpH}_{\mathrm{PtoDC} 3000}(\mathrm{HrpH}), \mathrm{HopP}_{\text {PtoDC3000 }}$ (HopP1), AvrPto, or pCPP3214 (vector) were infiltrated into Nicotiana benthamiana leaves at $2 \times 10^{8} \mathrm{CFU}$ $\mathrm{ml}^{-1}$ and were then challenged $6 \mathrm{~h}$ later with an overlapping inoculation of P. fluorescens(pLN18 + pCPP3221) expressing AvrPto-Cya at $2 \times 10^{7}$ $\mathrm{CFU} \mathrm{ml}{ }^{-1}$. At $6 \mathrm{~h}$ after the challenge inoculation, $1.0-\mathrm{cm}$ leaf disks were collected from areas of overlap between pretreatments and challenge inoculations. Cya translocation assays on disks from independent leaves were performed in triplicate, and the mean and standard deviation are shown. B, As depicted in the diagram, P. fluorescens(pLN18) cells carrying a second plasmid $(\mathrm{pX})$ expressing $\mathrm{HrpH}_{\mathrm{PtoDC} 3000}-\mathrm{Cya}(\mathrm{HrpH})$,

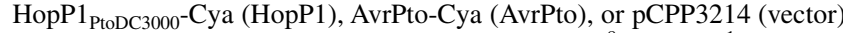
were infiltrated into $N$. benthamiana leaves at $2 \times 10^{8} \mathrm{CFU} \mathrm{ml}^{-1}$ and were challenged $6 \mathrm{~h}$ later with an overlapping inoculation of $P$. syringae pv. tomato DC3000 at $2 \times 10^{7} \mathrm{CFU} \mathrm{ml}^{-1}$. Leaves were photographed $24 \mathrm{~h}$ after the challenge inoculation. Confluent cell death was observed in the areas of overlapping inoculation marked with the continuous white line. corresponding genes are mutated in $P$. syringae pv. tomato DC3000 or other source pathogens. pHIR11 has been described as a "workhorse" and its toolbox has been recently expanded by stable integration of a derivative into the genome of $P$. fluorescens Pf-0 (Thomas et al. 2009). DC3000 effectors that suppress ETI have been identified by their ability to block HR elicitation by $P$. fluorescens(pHIR11) in tobacco (Guo et al. 2009; Jamir et al. 2004). Similarly, P. fluorescens carrying pLN18 and similar HopA $1_{\text {Psy61 }}$-deficient pHIR11 derivatives induce PTI in tobacco and Nicotiana benthamiana, unless expressing a PTI-suppressive effector, such as AvrPto (Guo et al. 2009; Oh and Collmer 2005).

In addition to effectors, substrates for the $P$. syringae T3SS include a variety of proteins that are thought to function in the pathway itself. These include the pilus subunit HrpA (Roine et al. 1997), putative lytic transglycosylases $\mathrm{HrpH}$ and HopP1 (Oh et al. 2007), harpin/translocators HrpZ1 (He et al. 1993), HrpW1 (Charkowski et al. 1998), and HopAK1 (Kvitko et al. 2007), conserved translocator HrpK1 (Petnicki-Ocwiega et al. 2005), and several proteins encoded in the core $\mathrm{hrp} / \mathrm{hrc}$ cluster that appear to have structural or regulatory roles, or both, in assembly of the T3SS, including HrpB, HrpD, HrpF, HrpJ, and HrpP (Ramos et al. 2007).

The putative lytic transglycosylases and harpin/translocators represent two classes of redundant factors that are important for effector translocation into host cells but not effector secretion into the bacterial milieu. HrpK1 is a member of a conserved family of T3SS translocon components and appears to be the most important translocator, although it functions redundantly with the HrpZ1, HrpW1, and HopAK1 harpins (Kvitko et al. 2007; Petnicki-Ocwiega et al. 2005). Harpins are glycine-rich, cysteine-lacking proteins that are unique to plant pathogens and can elicit plant defenses, including the HR, when purified and infiltrated into leaf intercellular spaces, but their role in defense elicitation during natural infections is less clear.

Specialized lytic transglycosylases associated with the T3SS of plant and animal pathogens are thought to act in the bacterial envelope to enable the peptidoglycan mesh to accommodate the T3SS machinery (Koraimann 2003). HrpH is typical of specialized lytic transglycosylases in having a soluble lytic transglycosylase superfamily 1 domain and being encoded in linkage with other T3SS genes. However, the $P$. syringae $\mathrm{HrpH}$ and HopP1 lytic transglycosylases are atypical because they are translocated into host cells (Oh et al. 2007). $\mathrm{HrpH}$ is also unlike the specialized lytic transglycosylases of animal and plant pathogens with Hrp2 T3SS (found in Ralstonia and Xanthomonas spp.) in being more than two times larger and possessing MLTD_N and Pfam-B domains and a novel, highly variable $\mathrm{C}$-terminal region $(\mathrm{Oh}$ et al. 2007). This suggests that $\mathrm{HrpH}$ may have multiple functions.

Here, we report several novel findings. i) P. syringae pv. tomato DC3000 is unable to deliver into PTI-protected tissue the model effector AvrPto fused to the translocation reporter Cya. ii) $\mathrm{HrpH}_{\mathrm{PtoDC} 3000}$ and $\mathrm{HrpP}_{\mathrm{PtoDC} 3000}$ function as well as the reference effector AvrPto in suppressing PTI when delivered by P. fluorescens(pLN18), as based on multiple assays for PTI. iii) HopA $1_{\mathrm{PtoDC} 3000}$ and HopA $1_{\mathrm{Psy} 61}$ are also suppressors of PTI. iv) The PTI-suppressive activity of HopA $1_{\text {Psy61 }}$ masks a hidden capacity of the pHIR11 T3SS to strongly elicit plant generation of ROS, another PTI marker. v) HrpK $1_{\text {Psy61 }}$ contributes strongly to this elicitor activity.

As a note on nomenclature, effectors are designated Avr (avirulence) or Hop (Hrp outer protein). The Hop designation is also used for more recently found T3SS substrates, such as HopAK1, that appear to be T3SS helpers rather than injected 
effectors but are encoded outside of the Hrp pathogenicity island. Because this report involves both $P$. syringae pv. tomato DC3000 and pHIR11, for several genes and their products, we will frequently use the extended notation of a unified nomenclature system, which includes a subscript denoting the source pathovar and strain (Lindeberg et al. 2005).

\section{RESULTS}

\section{P. fluorescens(pLN18)-induced PTI prevents challenge-inoculated bacteria from translocating AvrPto-Cya or eliciting the HR in N. benthamiana, but this effect can be reversed if the inducing bacteria deliver AvrPto, HrpH $_{\text {PtoDC3000, or HopP1 }}$ PtoDc3000.}

PTI develops within $6 \mathrm{~h}$ after infiltration of the leaf tissue of Nicotiana spp. with P. fluorescens and other nonpathogens (Klement et al. 2003; Oh and Collmer 2005). One indicator of PTI is that challenge inoculation of the same tissue with a strain of $P$. syringae that normally elicits the HR produces no visible response (Klement et al. 2003; Oh and Collmer 2005). Because HR elicitation by $P$. syringae requires T3SS delivery of effectors into plant cells, this observation suggests that the $P$. syringae T3SS no longer functions in PTIprotected tissue. To directly test this notion, we infiltrated $N$. benthamiana leaf tissue with $P$. fluorescens(pLN18, pCPP3214) at $1 \times 10^{8} \mathrm{CFU} \mathrm{m}{ }^{-1}$ and then made an overlapping infiltration $6 \mathrm{~h}$ later with $P$. fluorescens(pLN18) expressing avrPto-cya in trans. pLN18 is pHIR11 with shc $A_{P s y 61}-h o p A 1_{P s y 61}$ replaced with nptII (Jamir et al. 2004), pCPP3214 is an empty vector control (Schechter et al. 2004), and Cya (adenylate cyclase) is a reporter for translocation into eukaryotic cells (Casper-Lindley et al. 2002; Sory and Cornelis 1994). As shown in Figure 1A, the challenge bacteria translocate AvrPto-Cya into tissue mock-inoculated with buffer but not into tissue previously inoculated with $P$. fluorescens(pLN18, pCPP3214). A similar effect was observed when the inducing inoculum involved nonpathogens not expressing a $P$. syringae T3SS, such as Pseudomonas putida (data not shown). Thus, bacteria in tissue expressing PTI are impaired in their delivery of type III effectors.

We have previously shown that $P$. fluorescens(pLN18) can translocate AvrPto-Cya into N. benthamiana cells (Schechter et al. 2004) and that T3SS-delivered AvrPto-Cya is sufficient to suppress PTI, based on the challenge HR assay (Oh and Collmer 2005). Here, we constructed a derivative of vector pCPP3234 that introduces a stop codon at the $3^{\prime}$ terminus of a Gateway-cloned effector gene, thus preventing fusion with Cya. We used this plasmid to learn if P. fluorescens(pLN18) delivering AvrPto can restore the ability of a $P$. fluorescens(pLN18) challenge inoculum to translocate AvrPto-Cya. As shown in Figure 1A, AvrPto-Cya translocation by the challenge was observed. We then used the same stop-codon vector to produce $\mathrm{HrpH}_{\mathrm{PtoDC} 3000}$ and $\mathrm{HopP} 1_{\mathrm{PtoDC} 3000}$ without a Cya fusion and tested their ability to prevent $P$. fluorescens(pLN18) from inducing PTI-associated blockage of AvrPto-Cya delivery. Again, we observed AvrPto-Cya translocation by the challenge.

As expected, prior inoculation with $P$. fluorescens $(\mathrm{pLN} 18$, pCPP3214) also blocked the macroscopic HR (Fig. 1B). However, prior inoculation with $P$. fluorescens (pLN18) additionally producing $\mathrm{HrpH}_{\mathrm{PtoDC} 3000}-\mathrm{Cya}$ or $\mathrm{HopP} 1_{\mathrm{PtoDC} 3000}-\mathrm{Cya}$ permitted the challenge inoculation to elicit the HR. Thus, both the T3SS translocation and HR challenge assays indicate that the two DC3000 putative lytic transglycosylases that are produced in a HrpL-dependent manner and are T3SS substrates have PTI suppressive activity that is comparable to that of AvrPto.

\section{P. fluorescens(pLN18) producing $\mathrm{HrpH}_{\mathrm{PtoDC} 3000}$ or HopP1 $1_{\text {PtoDC3000 }}$ promotes the formation of GFP-labeled colonies in $N$. benthamiana} by challenge-inoculated $P$. syringae pv. tomato $\mathrm{DC} 3000$.

An important aspect of PTI is that protected tissue poorly supports the growth of bacterial pathogens. Although DC3000 elicits the HR in $N$. benthamiana, it does so relatively slowly in a manner dependent upon avirulence determinant HopQ1-1, which permits an initial period of T3SS-dependent bacterial growth (Wei et al. 2007). Thus, we can use the same DC3000-N. benthamiana pathosystem to assess another aspect of PTI. Furthermore, by using confocal laser-scanning microscopy and green fluorescent protein (GFP)-labeled DC3000 challenge bacteria, we could observe the pattern of bacterial colony development in treated leaf tissues. As shown in a representative microscopy field in Figure 2A, we observed no significant development of DC3000 colonies beyond scattered individual cells in tissue pretreated with $P$. fluorescens(pLN18) carrying an empty vector. Thus, plant cells in the pretreated tissue appear to be uniformly protected by PTI. In contrast, numerous developing GFP-labeled DC3000 colonies are distributed within tissue that has not been pretreated and, therefore, is not expressing PTI. Interestingly, this protection appears to end within a few plant cells of the perimeter of the treated area (data not shown), and it is clearly lacking from the sample point B depicted in Figure 2, which is only a few millimeters from the pretreated area. In contrast, when the $P$. fluorescens(pLN18) inducing inoculum delivered AvrPto-Cya, GFP-labeled DC3000 colonies now developed in the challenged tissue. Importantly, GFP-labeled colonies also developed in tissue in which the inducer inoculum delivered $\mathrm{HrpH}_{\mathrm{PtoDC} 3000^{-}}$ Cya and HopP $1_{\mathrm{PtoDC} 3000}-\mathrm{Cya}$. This effect was not observed with HrpW1-Cya. Counts of relative numbers of detectable challenge bacteria or colonies of any size in treated and untreated tissues provided another measure of suppressor activity (Fig. 2C). Thus, $\mathrm{HrpH}_{\mathrm{PtoDC} 3000}$ and $\mathrm{HopP}_{\mathrm{PtoDC}_{3000}}$ but not HrpW1 $1_{\mathrm{PtoDC} 3000}$ can suppress the ability of PTI to block bacterial growth.

\section{P. fluorescens(pLN18) producing $\mathrm{HrpH}_{\mathrm{PtoDC3000}}$ or HopP1 $1_{\text {PtoDC3000 }}$ suppresses PTI-associated reduction of vascular dye uptake \\ in inoculated $N$. benthamiana leaf areas.}

The previous three assays involved challenge inoculations to indicate development of the PTI-induced protected state in plant tissues. A physiological marker for PTI that can be directly assayed without a challenge inoculation involves the uptake of vascular dyes. This assay uses neutral red as a vascular dye to detect a reduction in water uptake into minor veins. This effect is possibly due to either stomatal closure, reduced xylem conductivity, or both and could be important in PTI, because local desiccation of leaf tissue is emerging as a major defense against bacteria (Freeman and Beattie 2009; Melotto et al. 2006; Oh and Collmer 2005). The PTI-associated reduction in dye uptake that can be observed by feeding neutral red through the base of excised petioles $6 \mathrm{~h}$ after inoculation with $P$. fluorescens(pLN18) can be documented both photographically and spectrophotometrically (Fig. 3). We have previously shown that $P$. fluorescens(pLN18) expressing AvrPto-Cya no longer elicits this response (Oh and Collmer 2005). Here, we observed that $\mathrm{HrpH}_{\mathrm{PtoDC} 3000}-\mathrm{Cya}$ and $\mathrm{HopP} 1_{\mathrm{PtoDC} 3000}-\mathrm{Cya}$ have a similar ability to suppress this PTI-associated plant response that is otherwise induced by $P$. fluorescens(pLN18).

\section{P. fluorescens(pLN18) producing $\mathrm{HrpH}_{\mathrm{PtoDC} 3000}$ or HopP1 $1_{\text {PtoDC3000 }}$ Suppresses PTI-associated callose production in $N$. benthamiana.}

Another PTI-associated marker that can be directly assayed without a challenge inoculation involves the formation of cal- 
lose deposits, which are considered to indicate cell wall-based defenses (Hauck et al. 2003). Here, we inoculated leaves with $P$. fluorescens(pLN18) carrying an empty vector or expressing $\mathrm{HrpH}_{\mathrm{PtoDC} 3000}-\mathrm{Cya}, \mathrm{HopP}_{\mathrm{PtoDC} 3000}-\mathrm{Cya}$, or AvrPto-Cya at $1 \times$ $10^{8} \mathrm{CFU} \mathrm{ml} \mathrm{m}^{-1}$ and, $6 \mathrm{~h}$ later, assayed for callose deposits using aniline blue and fluorescence microscopy. Typical microscopy fields and callose deposit counts from several experiments are presented in Figure 4, and they show that $P$. fluorescens (pLN18), in contrast to buffer control, induces callose formation. Importantly, $\mathrm{HrpH}_{\mathrm{PtoDC} 3000}-\mathrm{Cya}, \mathrm{HopP}_{\mathrm{PtoDC} 3000}-\mathrm{Cya}$, and AvrPto-Cya all suppress this response.
Unlike HrpH $H_{\mathrm{PtoDC} 3000}, \mathrm{HrpH}_{\mathrm{Psy} 61}$ expressed in trans in $P$. fluorescens(pLN18) appears unstable and does not suppress PTI-associated ROS production in $N$. benthamiana cells.

A puzzling aspect of the foregoing results is that, in multiple assays, $\mathrm{HrpH}_{\mathrm{PtoDC} 3000}$ is able to suppress the PTI that is induced by $P$. fluorescens(pLN18), despite the fact that the hrp gene cluster cloned in pLN18 includes the native $h r p H_{P s y 61}$. Furthermore, the $h r p H_{P s y 61}$ gene appears to be functional, because deleting it strongly reduces the ability of pHIR 11 derivatives to translocate HopA $1_{\text {Psy61 }}-$ Cya into plant cells (Oh et al. 2007).
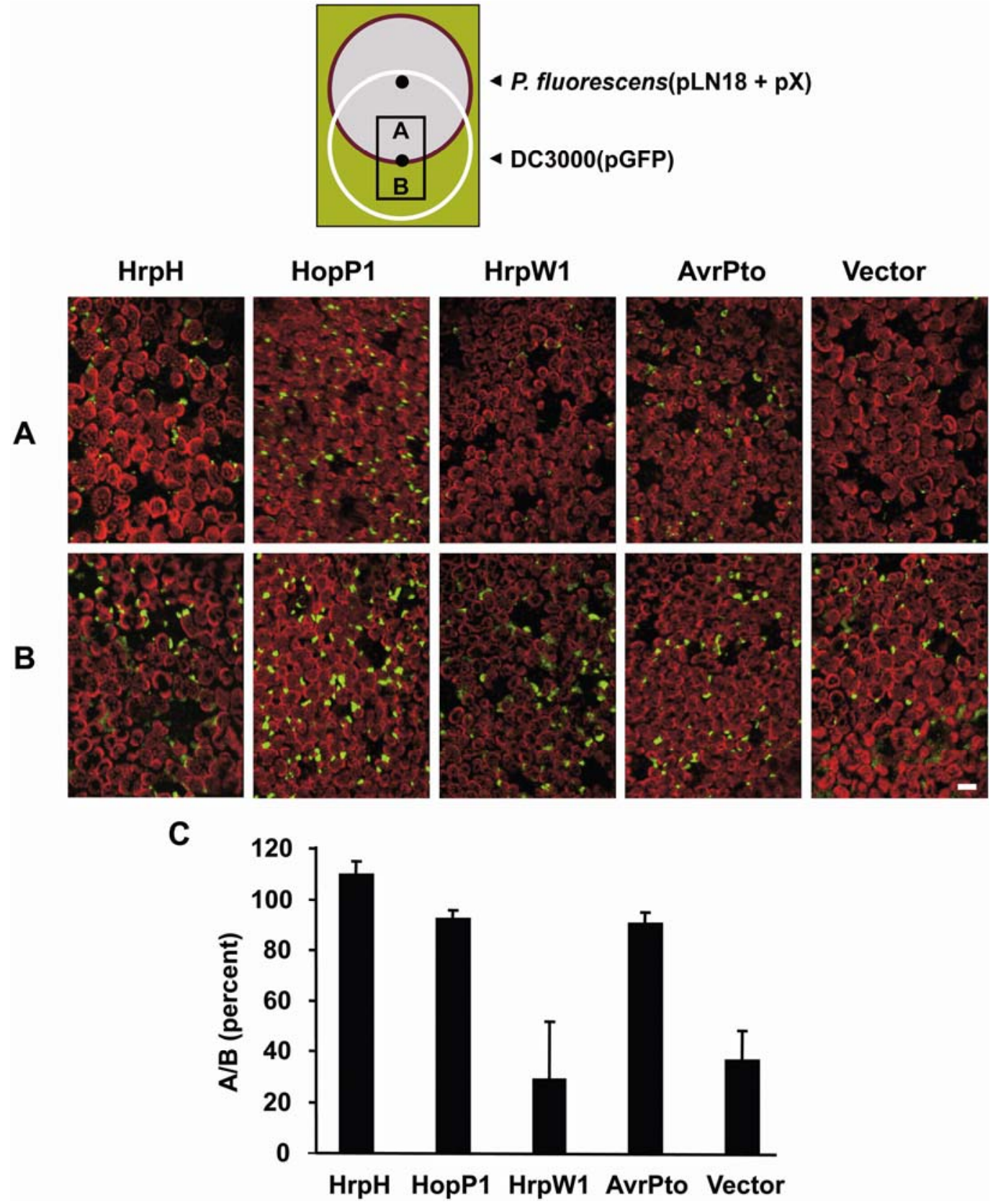

Fig. 2. $\mathrm{HrpH}_{\mathrm{PtoDC} 3000}$ and $\mathrm{HopP} 1_{\mathrm{PtoDC} 3000}$, delivered by P. fluorescens expressing a Pseudomonas syringae type III secretion system (T3SS), are able to suppress pathogen-associated molecular pattern-triggered immunity (PTI) in Nicotiana benthamiana, as indicated by colonization of DC3000 expressing green fluorescent protein (GFP). As depicted in the diagram, P. fluorescens(pLN18) strains carrying a second plasmid (pX) expressing HrpH-Cya (HrpH), $\mathrm{HopP}_{\mathrm{PtoDC} 3000}-\mathrm{Cya}(\mathrm{HopP} 1), \mathrm{HrpW} 1_{\mathrm{PtoDC} 3000}-\mathrm{Cya}(\mathrm{HrpW} 1)$, AvrPto-Cya (AvrPto), and pCPP3214 (vector) were infiltrated into N. benthamiana leaves at 2 $\times 10^{8} \mathrm{CFU} \mathrm{ml}{ }^{-1}$ and were challenged $6 \mathrm{~h}$ later with an overlapping inoculation of GFP-expressing P. syringae pv. tomato DC3000(pCPP3069) at $2 \times 10^{7}$ $\mathrm{CFU} \mathrm{ml}{ }^{-1}$. At $6 \mathrm{~h}$ after the challenge inoculation, GFP-labeled bacteria were visualized by confocal microscopy. Representative microscopy fields from A, overlapping areas pretreated with P. fluorescens (pLN18) strains and $\mathbf{B}$, areas treated with only challenge bacteria. Scale bar $=50 \mu \mathrm{m}$. $\mathbf{C}$, Relative numbers of detectable bacteria or colonies counted in three independent microscopy images obtained as in rows A and B. Data are expressed as the mean percentage of A relative to $\mathrm{B}$ and the standard deviation. 
One possible explanation is that the ability of $\mathrm{HrpH}_{\mathrm{PtoDC} 3000}$ to suppress PTI in our assays is dependent upon its expression in trans as a Cya fusion driven by a vector tac promoter. Alternatively, $\mathrm{HrpH}_{\mathrm{PtoDC} 3000}$ and $\mathrm{HrpH}_{\mathrm{Psy} 61}$ may be intrinsically different in this ability. To address this issue, we inserted $h r p H_{P s y 61}$ into the same vector backbone used to express $\mathrm{HrpH}_{\mathrm{PtoDC} 3000^{-}}$ Cya, and we assayed for the ability of the two proteins to be translocated into plant cells by $P$. fluorescens( $\mathrm{pLN} 18)$ and to suppress defense-associated generation of ROS, a convenient and quantitative assay that has been used in $N$. benthamiana (Hann and Rathjen 2007). To permit further comparison of the performance of T3SS substrates produced by DC3000 and the

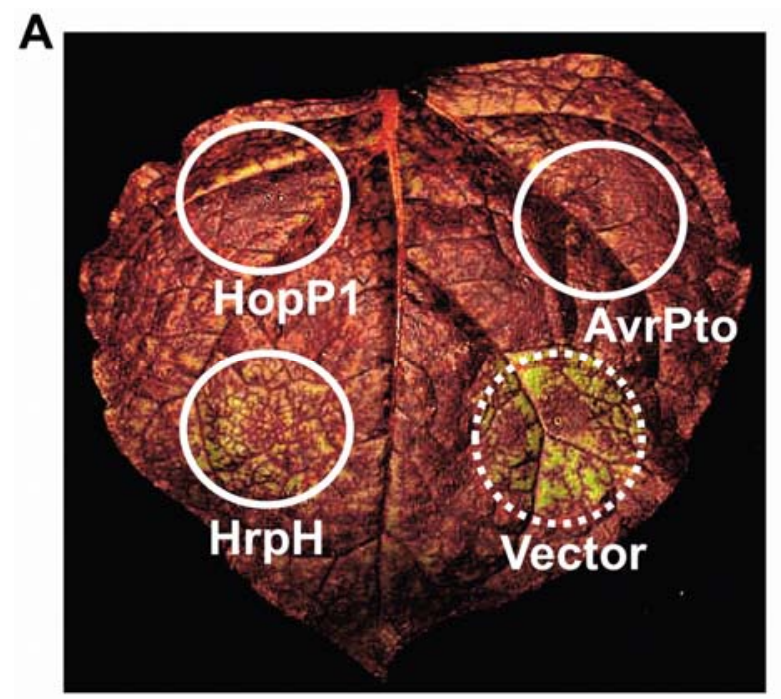

B

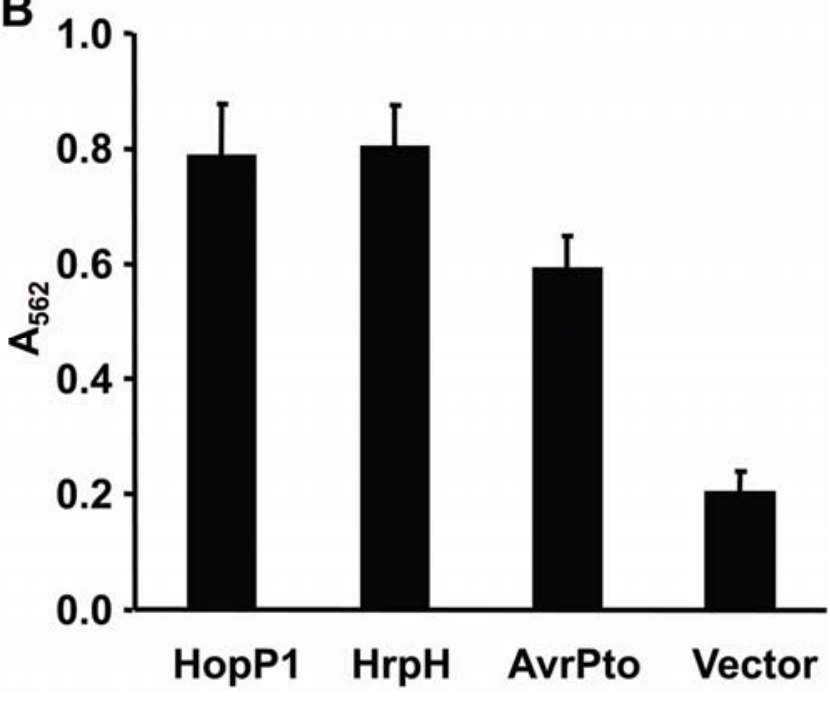

Fig. 3. $\mathrm{HrpH}_{\mathrm{PtoDC} 3000}$ and $\mathrm{HopP}_{\mathrm{PtoDC} 3000}$ delivered by Pseudomonas fluorescens expressing a $P$. syringae type III secretion system (T3SS) are able to suppress pathogen-associated molecular pattern-triggered immunity (PTI) as indicated by the vascular-staining assay in Nicotiana benthamiana. P. fluorescens(pLN18) strains expressing $\mathrm{HrpH}-\mathrm{Cya}(\mathrm{HrpH})$, $\mathrm{HopP}_{\mathrm{PtoDC} 3000}-\mathrm{Cya}$ (HopP1), AvrPto-Cya (AvrPto), or pCPP3214 (vector) were infiltrated into $N$. benthamiana leaves at $2 \times 10^{8} \mathrm{CFU} \mathrm{ml}^{-1}$. A, Differential accumulation of neutral red in minor veins of inoculated leaf areas (white circles) was observed. At $6 \mathrm{~h}$ after infiltration, leaves were detached at the base of the petiole using a razor blade, the petioles were immersed in $1 \%$ neutral red solution, and $12 \mathrm{~h}$ later, the leaves were photographed. B, For quantitative analysis of dye accumulation in treated leaf tissues, $0.5-\mathrm{cm}$ leaf disks were excised $12 \mathrm{~h}$ after petioles were placed in neutral red solution and dye was extracted into ethanol and measured by spectrophotometry. The results are the mean and standard deviation of five samples.
pHIR11 system in these assays, we analyzed HopA $1_{\text {PtoDC3000 }}$ and HopA $1_{\text {Psy61 }}$ as well as our positive control AvrPto. As expected, $\mathrm{HrpH}_{\mathrm{PtoDC} 000^{-}} \mathrm{Cya}, \mathrm{AvrPto}_{\mathrm{PtoDC} 3000^{-}} \mathrm{Cya}$, and HopA1 PtoDC3000Cya were translocated by $P$. fluorescens $(\mathrm{pLN} 18)$, and HopA $1_{\text {Psy61 }}$-Cya was translocated by pCPP5316 (a pHIR11

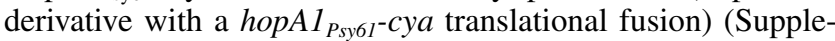
mentary Fig. S1A). Furthermore, all of these proteins suppressed ROS production in comparison with the vector control.

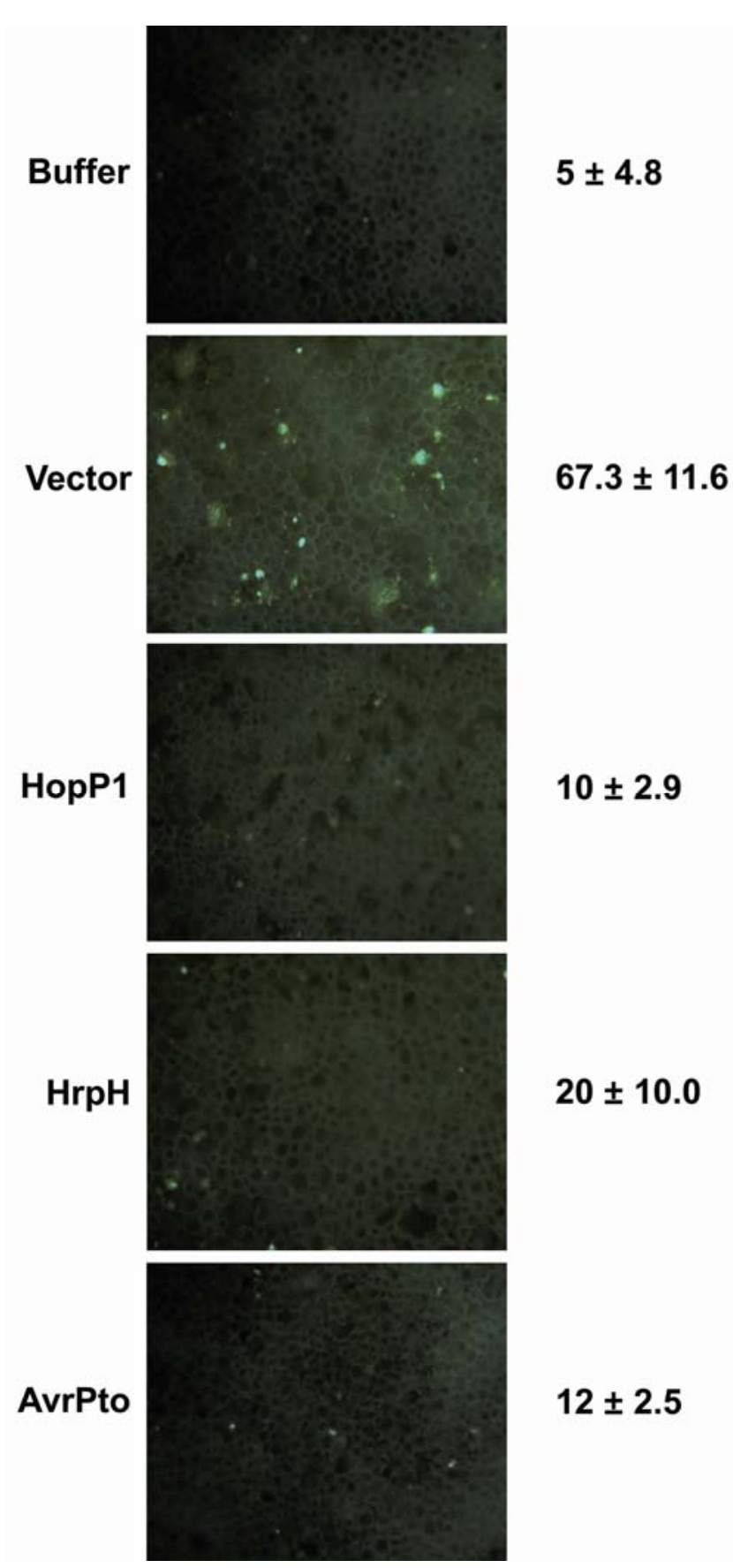

Fig. 4. $\mathrm{HrpH}_{\mathrm{PtoDC} 3000}$ and $\mathrm{HopP} 1_{\mathrm{PtoDC} 3000}$ delivered by Pseudomonas fluorescens expressing $P$. syringae type III secretion system (T3SS) are able to suppress pathogen-associated molecular pattern-triggered immunity (PTI), as indicated by callose deposition in Nicotiana benthamiana. P. fluorescens(pLN18) strains carrying a second plasmid expressing HopP $1_{\mathrm{PtoDC}_{3000^{-}}}$ Cya (HopP1), HrpH PtoDC3000-Cya (HrpH), AvrPto-Cya (AvrPto), and pCPP3214 (vector) were infiltrated into $N$. benthamiana leaves at $2 \times 10^{8}$ $\mathrm{CFU} \mathrm{ml}{ }^{-1}$, and $24 \mathrm{~h}$ later, leaf disks from infiltrated areas were excised for callose staining. Callose deposits, stained with aniline blue, were visualized and counted by epifluorescence microscopy. 
In contrast, $\mathrm{HrpH}_{\mathrm{Psy61}}$-Cya was not translocated by $P$. fluorescens $(\mathrm{pLN} 18)$ and did not suppress ROS production. Furthermore, immunoblot analysis of cell lysates of P. fluorescens(pLN18) expressing the proteins tested confirmed the accumulation of all of the proteins tested except for $\mathrm{HrpH}_{\mathrm{Psy61}^{-}}$Cya. This observation was consistent with an apparent toxicity of $\mathrm{HrpH}_{\mathrm{Psy} 61}$, as indicated by the comparatively slower growth of $P$. fluorescens (pLN18) carrying $h r p H_{P s y 61^{-}}$-cya (data not shown) and by the observed inhibition of $E$. coli growth following isopropyl $\beta$-D-thiogalactopyranoside (IPTG)-induced expression of $h r p H_{P s y 61}$. We previously reported the toxicity of $\mathrm{HrpH}_{\mathrm{PtoDC} 3000}$ when expressed in E. coli (Oh et al. 2007), but we have not observed $\mathrm{HrpH}_{\mathrm{PtoDC} 3000}$ to have any effect on the growth of $P$. fluorescens(pLN18). As previously noted, the $P$. syringae $\mathrm{HrpH}$ proteins are exceptional among T3SSassociated lytic transglycosylases in their large size and possession of the Pfam-B domain and C-terminal extension. Interestingly, comparison of $\mathrm{HrpH}_{\mathrm{PtoDC} 3000}$ and $\mathrm{HrpH}_{\mathrm{Psy61}}$ using BLOSUM62 reveals that amino acids 351 through 480 are only $26.9 \%$ identical and $38.5 \%$ similar in this region, which occurs between the Pfam-B domain and the highly conserved $\mathrm{C}$-terminal 35 amino acids. Whatever the basis for the instability and toxicity of $\mathrm{HrpH}_{\mathrm{Psy}_{61}}$, we were unable to use gain-of-function tests in our P. fluorescens (pLN18) system to determine if $\mathrm{HrpH}_{\mathrm{Psy} 61}$ also has an ability to suppress PTI.

\section{Analysis of pHIR11 mutants expressed in P. fluorescens reveals that the $P$. syringae pv. syringae 61 T3SS strongly elicits ROS production unless suppressed by HopA1 $1_{\text {Psy61 }}$.}

We had previously used the pHIR11 system to show that $\mathrm{HrpH}_{\text {Psy61 }}$ was needed for the translocation of HopA1 $1_{\text {Psy61-Cya }}$ into $N$. benthamiana and for HopA $1_{\text {Psy61-dependent } \mathrm{HR} \text { elicita- }}$ tion in tobacco (N. tabacum cv. Xanthi) (Oh et al. 2007). In the present work, we learned that $\mathrm{HrpH}_{\mathrm{PtoDC} 3000}$ and $\mathrm{HopA} 1_{\mathrm{PtoDC} 3000}$ can suppress PTI-associated ROS production in $N$. benthamiana. These observations raised the possibility of complex interplay between $\mathrm{HrpH}_{\mathrm{Psy} 61}$ and HopA $1_{\mathrm{Psy} 61}$ and other components of the pHIR11 T3SS in both eliciting and suppressing plant defenses. Accordingly, we assembled a series of pHIR11 mutants and analyzed them in P. fluorescens, using the ROS assay in $N$. benthamiana. The mutant plasmid designations and their genotypes are summarized in Figure 5, along with a physical map of the $h r p / h r c$ genes. The mutations involved hop $A_{P s y 61}$ and $h r p H_{P s y 61}$ as well as genes encoding three other factors thought to control distinct steps in the T3SS pathway, $\mathrm{HrcV}_{\mathrm{Psy61}}$, a core component of the T3SS that is essential for secretion of T3SS substrates across the inner membrane (Charkowski et al. 1997) and HrpZ1 $1_{\text {Psy61 }}$ and HrpK $1_{\text {Psy61 }}$, which are members of distinct protein families that redundantly contribute to the translocation of effectors across plant cell barriers (Kvitko et al. 2007; Petnicki-Ocwiega et al. 2005). Test bacteria were infiltrated into $N$. benthamiana leaf tissue at $2 \times 10^{8} \mathrm{CFU} \mathrm{ml}{ }^{-1}$ and were assayed for ROS production $15 \mathrm{~h}$ later (Fig. 5). Analysis of these results, from left to right in Figure 5A, reveals pHIR11 components that suppress and possibly elicit PTI, as summarized in the Figure 5B model.

Comparing the buffer and $P$. fluorescens treatments demonstrates that, as expected, P. fluorescens elicits ROS production. However, comparing $P$. fluorescens with $P$. fluorescens carrying either pHIR11 or pCPP5316 reveals that HopA $1_{\text {Psy61 }}$ must be able to suppress the ROS that $P$. fluorescens would otherwise elicit, and the Cya fusion does not diminish this ability. The latter observation is consistent with our observations with other T3SS substrates, such as $\mathrm{HrpH}_{\mathrm{PtoDC} 3000}$ and AvrPto, that a C-terminal Cya fusion (which enables confirmation that the protein is translocated in assays for function) does not interfere with biological activity in planta.

The contrasting strong ROS elicitation by pLN18 reveals two more things. First, the T3SS itself contributes to strong ROS elicitation that is substantially above the level that would otherwise be elicited by $P$. fluorescens PAMPs (compare $P$. fluorescens without a T3SS plasmid with $P$. fluorescens carrying pLN18). Second, HopA1 $1_{\text {Psy61 }}$ is capable of suppressing the ROS that are elicited by both P. fluorescens PAMPs and T3SS factors (compare pHIR11, pLN18, and no T3SS plasmid).

The $h r c V_{P s y 61}$ mutant cannot secrete HopA $1_{\text {Psy61 }}$ but, nevertheless, elicits the same intermediate level of ROS as $P$. fluorescens without a T3SS plasmid and not the high level elicited by pLN18. This suggests that the T3SS-associated ROS elicitor is a T3SS substrate that must be secreted beyond the bacterial inner membrane to be active.

The next three mutants shown in Figure 5 are lacking $h o p A 1_{P_{s y 61}}$ and either $h r p H_{P_{s y 61}}, h r p Z 1_{P_{s y 61}}$, or $h r p K 1_{P_{s y 61}}$. The hopA $1_{P s y 61} / h_{p p H} H_{P s y 1}$ mutant is not significantly different from the pLN18. In contrast the hopA $1_{P_{s y 61}} / h r p K 1_{P_{s y 61}}$ mutant is the most reduced in ROS elicitation and is not significantly different from the $P$. fluorescens strains with no T3SS plasmid or the $h r c V_{P s y 61}$ mutant. The hopA $1_{P_{s y 6 l}} /$ hrpZ $1_{P_{s y 6 l}}$ mutant is intermediate among these three treatments in its ROS phenotype. Thus, HrpK $1_{\text {Psy61 }}$ appears to be particularly important in T3SSassociated ROS elicitation, although $\mathrm{HrpZ}_{\mathrm{Psy} 61}$ may make a minor contribution.

\section{DISCUSSION}

Cosmid pHIR11 encodes the first T3SS from plant or animal pathogens to be shown to function heterologously in nonpathogens (Huang et al. 1988), and studies with pHIR11 provided early evidence that $h r p$ genes direct effector translocation into plant cells (Gopalan et al. 1996; Pirhonen et al. 1996). In recent years, $P$. fluorescens strains carrying derivatives of pHIR11 have proven useful in studying the ability of individual $P$. syringae pv. tomato DC3000 effectors to perform important functions in bacterium-plant interactions, such as suppression of PTI and ETI or elicitation of ETI. Here, we have used pHIR11 derivatives to learn that components and functions of the $P$. syringae T3SS itself interact with plant defenses. Notably, the T3SS does not deliver effectors into PTI-protected tissue, T3SS-associated lytic transglycosylases can suppress PTI, and pHIR11 has a capacity to enhance elicitation of ROS, which is strongly dependent upon the HrpK1 translocator. Our discussion will focus on these findings, new questions they raise, and their relevance to the concept of host recognition of "patterns of pathogenesis" that is emerging from studies with animal pathogens (Vance et al. 2009).

An important feature of PTI-protected leaf tissue is that it supports neither growth of a virulent pathogen nor HR elicitation by an avirulent pathogen. The HR has been used as an assay readout for T3SS-mediated translocation of effectors in systems in which the tested effector or its fusion partner carries an avirulence determinant (Chang et al. 2005; Guttman and Greenberg 2001; Mudgett and Staskawicz 1999). Thus, the simplest explanation for the failure of bacteria to elicit the HR in PTI-protected tissue is that effectors are no longer being delivered. We have tested that notion here by using Cya rather than the HR as a reporter for translocation and found that a reference T3SS substrate, AvrPto-Cya, is indeed no longer translocated. However, we do not have any evidence that PTI acts directly against the T3SS per se, for example, by rendering the plant cell wall impenetrable to the Hrp pilus. On the contrary, our use of GFP-labeled DC3000 and confocal microscopy to monitor the development of bacterial colonies in 

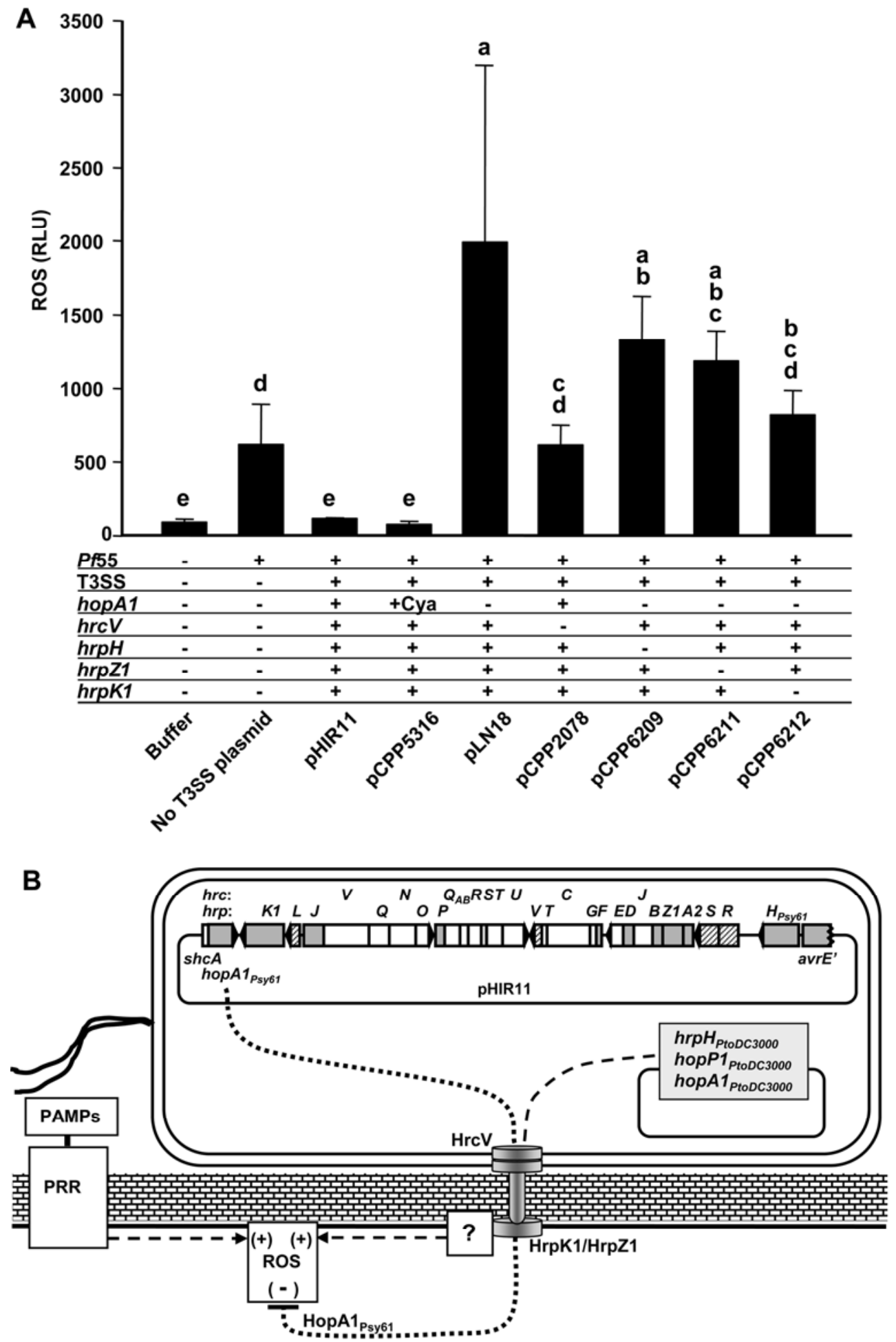

Fig. 5. Analysis of key pHIR11 mutants expressed in Pseudomonas fluorescens suggests a bacterium-plant interaction model in which a functional P. syringae type III secretion system (T3SS) can elicit strong reactive oxygen species (ROS) production in Nicotiana benthamiana, but all ROS production is suppressed by HopA $1_{\text {Psy61 } 1}$ A, P. fluorescens cells lacking pHIR11 or carrying pHIR11 or one of the indicated derivatives were infiltrated at $2 \times 10^{8} \mathrm{CFU} \mathrm{ml}^{-1}$ into $N$. benthamiana leaves and were assayed for ROS production $15 \mathrm{~h}$ later. In the genotype table "+Cya" indicates that HopA $1_{\text {Psy61 } 1}$ is produced as a Cya fusion. ROS assay results are presented as the arithmetic mean and standard deviation based on three independent experiments of two samples from different plants in each experiment. Mean $\log (\mathrm{ROS})$ was determined to be not significantly different among experiments based on an analysis of variance randomized block analysis. The Tukey highly significant difference multiple comparisons procedure was performed on log-transformed values of the six assays for each pair of treatments; treatments with the same letter are not significantly different $(P=0.05)$. B, The model depicts $P$. fluorescens interacting with a plant cell and the factors involved in elicitation or suppression of ROS. Genes encoding proteins that are substrates for the T3SS are shaded; genes encoding regulators have diagonal hatching. P. fluorescens presents pathogen-associated molecular patterns (PAMPs), which are recognized by plant pattern-recognition receptors (PRR) leading to PAMP-triggered immunity and ROS production. P. fluorescens carrying pHIR11 derivatives that produce a T3SS capable of deploying the HrpK1 translocator elicit higher levels of ROS, but what plants recognize is unknown. All ROS production can be suppressed by the native HopA1 Psy61 $_{\text {or, in }}$ its absence, $\mathrm{HrpH}_{\mathrm{PtoDC} 3000}$, HopP1 $1_{\mathrm{PtoDC} 3000}$, or $\mathrm{HopA} 1_{\mathrm{PtoDC} 3000}$ produced in trans from a plasmid. HrcV is necessary for T3SS export across the bacterial inner membrane. HrpK1 and secondarily HrpZ1 are thought to function as translocators in the host plasma membrane. HrpH is necessary for effector translocation, but its site of action has not been defined. 
infected tissue revealed a uniform failure of bacteria to grow in PTI-protected tissue. Furthermore, the GFP signal from such bacteria was generally weaker than that from T3SS-deficient DC3000 mutants in naïve tissue (data not shown), which suggests that the T3SS may fail in PTI-protected tissue because of general stresses on the bacteria. Whatever its basis, the challenge inoculum Cya translocation assay provides a useful functional test for the PTI-protected state and its suppression.

Remarkably, $\mathrm{HrpH}_{\mathrm{PtoDC} 3000}$ and $\mathrm{HopP} 1_{\mathrm{PtoDC} 3000}$ suppressed PTI, based on the challenge inoculum translocation and growth assays as well as on the vascular dye and callose assays, which involve altered water relations and cell-wall appositions implicated in plant defense. Although both of these proteins have soluble lytic transglycosylase domains, are produced in a HrpLdependent manner, and are translocated by the T3SS, they have different structural features. HopP1 is typical of two-domain harpins, such as HrpW $1_{\text {PtoDC3000 }}$ and HopAK $1_{\text {PtoDC3000 }}$. The $\mathrm{N}$ terminal half of these proteins is harpin-like and the C-terminal half has an enzyme-like domain, with HrpW $1_{\text {PtoDC3000 }}$ and HopAK $1_{\text {PtoDC3000 }}$ carrying pectic enzyme domains (Kvitko et al. 2007). Notably, the pectic enzyme-like harpins appear to function redundantly with the $\mathrm{HrpK} 1_{\mathrm{PtoDC} 3000}$ translocator, whereas HopP $1_{\text {PtoDC3000 }}$ does not (Kvitko et al. 2007). In this study, we included HrpW1 $1_{\mathrm{PtoDC} 3000}$ in the challenge growth assay for PTI suppression and found no evidence that it shared with HopP $1_{\text {PtoDC3000 }}$ the ability to suppress PTI. We chose $\mathrm{HrpW} 1_{\mathrm{PtoDC} 3000}$ for this test because it is widespread in plant pathogenic bacteria and the harpin domains of HopP $1_{\mathrm{PtoDC} 3000}$ and $\mathrm{HrpW} 1_{\text {PtoDC3000 }}$ are similar (Fouts et al. 2002; Kvitko et al. 2007). Thus, it appears that proteins with the two-domain harpin structure can serve distinct functions. The hopPl gene appears to be of limited distribution in $P$. syringae strains. It is found in the sequenced genome of $P$. syringae pv. tomato T1 but not in genomes of $P$. syringae pv. syringae $\mathrm{B} 728 \mathrm{a}$ and $P$. syringae $\mathrm{pv}$. phaseolicola 1448A, and it is not linked to the hrp/hrc gene cluster in DC3000 or T1 (Almeida et al. 2009; Lindeberg et al. 2006).

The $h r p H$ gene, in contrast, appears universally associated with the hrp/hrc genes in $P$. syringae strains, and it makes the strongest contribution of the DC3000 HrpL-activated putative lytic transglycosylases $\left(\mathrm{HrpH}_{\mathrm{PtoDC} 3000}, \mathrm{HopP} 1_{\mathrm{PtoDC} 3000}\right.$, and HopAJ $\left.1_{\text {PtoDC3000 }}\right)$ to effector translocation and associated phenotypes, based on studies with the pHIR11 system and DC3000 (Oh et al. 2007). Notably, $h r p H_{P t o D C 3000}$ was one of the DC3000 genes found to be upregulated in planta and to have a virulence defect when mutated (Boch et al. 2002).

Although $\mathrm{HrpH}_{\mathrm{PtoDC} 3000}$ has a capacity to suppress PTI, there are several reasons why it is difficult to assess the importance of that activity in either promoting effector translocation or virulence in DC3000. First, like many T3SS substrates, HrpH has multiple domains and, therefore, may have multiple functions (Cunnac et al. 2009). Thus, the promotion of effector translocation and suppression of PTI may be attributable to different domains and be mechanistically distinct. Second, we cannot study the potential of $\mathrm{HrpH}_{\mathrm{PtoDC} 3000}$ to suppress PTI in its native DC3000 background because of the confounding effects of the many PTI-suppressive effectors. Third, $\mathrm{HrpH}_{\mathrm{Psy61}}$ differs from $\mathrm{HrpH}_{\mathrm{PtoDC} 3000}$ in having no demonstrable PTI-suppressive activity in gain-of-function tests, although the test is confounded by the greater toxicity and instability of heterologously expressed $\mathrm{HrpH}_{\mathrm{Psy61}}$. However, the native $h r p H_{P s y 61}$ appears to have no PTI-suppressive activity in pHIR11 derivatives lacking hopA $1_{P s y 61}$. This observation is consistent with the hypothesis that the PTI-suppressive activity may be in the highly variable $\mathrm{C}$-terminal region and that the two $\mathrm{HrpH}$ proteins are functionally different in this capacity. Fourth, we have no mechanistic explanation for why proteins with soluble lytic transglycosylase domains, like $\mathrm{HrpH}_{\mathrm{PtoDC} 3000}$ and HopP $1_{\text {PtoDC3000, should have the PTI-suppressive activity we }}$ observed. Although peptidoglycan has been shown to be a PAMP that is recognized by plants (Gust et al. 2007), our assays involve elicitation of PTI with living P. fluorescens cells that would be expected to present multiple PAMPs to $N$. benthamiana cells. This argues against $\mathrm{HrpH}_{\mathrm{PtoDC} 3000}$ and HopP $1_{\text {PtoDC3000 }}$ functioning by interfering specifically with peptidoglycan perception. One possibility is that the acquisition of a C-terminal PTI-suppressive domain by the universal T3SSassociated lytic transglycosylase is an innovation in $P$. syringae evolution that exploits the likelihood that $\mathrm{HrpH}$ is among the first T3SS substrates to enter the pathway and, therefore, among the first to enter the plant cell. In future work, we will explore the relationship between the different domains of $\mathrm{HrpH}_{\mathrm{PtoDC} 3000}$ and functions in translocation and PTI suppression as well as the basis for the different properties of $\mathrm{HrpH}_{\mathrm{PtoDC} 3000}$ and $\mathrm{HrpH}_{\mathrm{Psy} 61}$. Finally, because either $\mathrm{HrpH}_{\mathrm{PtoDC} 3000}$ or HopP $1_{\mathrm{PtoDC} 3000}$ can at least partially restore the capacity to translocate $\mathrm{HopA}_{\mathrm{Psy61}}$ to a $h r p H_{P s y 61}$ deletion derivative of pHIR11 (Oh et al. 2007), whereas AvrPto, a known PTI-suppressive effector, fails to do so (data not shown), we tentatively consider these putative lytic transglycosylases to be T3SS "helpers" rather than true effectors.

Our finding that HopA $1_{\mathrm{Psy} 61}$ is a potent suppressor of PTI that masks a hidden ability of pHIR11 to strongly elicit ROS was unexpected. Previous studies had used either P. fluorescens(pHIR11), in tobacco to identify effectors that suppress ETI (exploiting the native HopA $1_{\text {Psy61 }}$ as an ETI elicitor), or $P$. fluorescens(pLN18) (lacking hopA $1_{P s y 61}$ ), in $N$. benthamiana to identify effectors that suppress PTI. However, HopA1 itself had not been tested for its ability to suppress PTI. By using the quantitative ROS assay for defense elicitation in $N$. benthamiana, we were able to show that pLN18 elicits higher levels of ROS than P. fluorescens without any plasmid. Similarly, in a recent publication, $P$. fluorescens Pf-0 carrying pLN18 integrated into the genome is reported to elicit an occasional, spotty necrosis in tobacco leaves (Thomas et al. 2009). Importantly, we have shown that elicitation of this higher level of ROS requires that the T3SS is able to secrete proteins beyond the bacterial envelope and that, among genes encoding extracellular Hrp proteins that we tested, the $h r p K 1_{P_{s y 61}}$ mutant was most strongly reduced in ROS elicitation. It is also noteworthy that either HopA $1_{\text {PtoDC3000 }}$ or HopA $1_{\text {Psy61 }}$ can suppress ROS production attributable to both $P$. fluorescens PAMPs and the T3SS.

HrpK $1_{\text {PtoDC3000 }}$ shows weak similarity to the $\mathrm{HrpF} / \mathrm{PopF}$ family of T3SS translocators of Xanthomonas and Ralstonia spp., and it has a predicted C-proximal transmembrane domain like other T3SS translocators (Petnicki-Ocwiega et al. 2005). hrpKl mutants of $P$. syringae pv. phaseolicola, DC3000, and pHIR11 are only partially reduced in HR elicitation activity, which is consistent with the observation that HrpZ1 and other harpins can function redundantly (Kvitko et al. 2007; Mansfield et al. 1994; Petnicki-Ocwiega et al. 2005). We cannot say that HrpK1 is the T3SS-associated ROS elicitor, because of the possibility that it promotes the translocation of another factor. In this regard, it is noteworthy that transgenic expression of HrpK1 in tobacco had no effect on the moderate ability of $P$. fluorescens carrying a $\Delta h r p K 1$ pHIR 11 derivative to elicit the HR (Petnicki-Ocwiega et al. 2005). This argues against HrpK1 itself being the elicitor, although its elicitor activity may require insertion by a T3SS tip complex into the host plasma membrane (Blocker et al. 2008).

The HrpZ1 $1_{\text {Psy61 }}$ harpin was high on the list of candidate elicitors of T3SS-dependent ROS production, based on the ability of exogenously applied HrpZ1 proteins to elicit the HR in so- 
lanaceous plants (He et al. 1993; Preston et al. 1995). Surprisingly, deleting $h r p Z 1_{P s y 61}$ had little effect on the ability of pLN18 to elicit ROS in $N$. benthamiana. It is also important to note that deleting $\mathrm{hrpH}_{P_{s y 6 l}}$ did not significantly reduce ROS elicitation. Since $\mathrm{HrpH}$ appears to be essential for effector translocation, this argues that the fragment of the gene at one end of the pHIR11 insert DNA that encodes the first one third of AvrE is unlikely to be responsible for ROS elicitation.

$P$. syringae pv. syringae $61 \mathrm{Hrp}$ proteins that are also T3SS substrates, based on Cya reporter fusions, have been comprehensively identified, and their contribution to diagnostic T3SS functions has been studied with nonpolar mutations (Ramos et al. 2007). Any one of these could potentially be perceived by plants and thereby elicit ROS. Unfortunately, mutations affecting the corresponding genes (other than hrpJ) disrupt the T3SS pathway, as indicated by the failure to secrete or translocate AvrPto-Cya. Similarly, mutation of the hrpA pilus subunit gene in $P$. syringae disrupts both secretion and translocation of T3SS substrates (Wei et al. 2000). Thus, the pleiotropic nature of these mutations confounds their use in identifying another elicitor of ROS. Transient expression in N. benthamiana, using Agrobacterium tumefaciens, is one potential approach for future efforts to identify the T3SS-associated ROS elicitor.

Another unresolved issue is whether $P$. fluorescens(pLN18) induces PTI or ETI. For several reasons, we postulate that the defenses induced by $P$. fluorescens(pLN18) are fundamentally PTI. First, pLN18 encodes no intact effectors. Second, heterologously expressed DC3000 effectors that fail to suppress the ETI induced by pHIR11-encoded HopA $1_{\text {Psy61 }}$ in tobacco, such as AvrPto and HopG1 (Jamir et al. 2004), are, nevertheless, able to suppress the defenses induced by pLN18 (Oh and Collmer 2005). This is particularly significant, because AvrPto has been shown by independent approaches to be a suppressor of PTI (Hauck et al. 2003). Third, P. fluorescens without any $P$. syringae T3SS is also able to induce defenses against HR and disease-associated plant cell death in overlapping challenge inoculation assays identical to those employed here (Chakravarthy et al. 2010). Furthermore, virus-induced gene silencing revealed that silencing FLS2 in N. benthamiana prevented P. fluorescens from inducing PTI based on these challenge-inoculum cell assays (Chakravarthy et al. 2010). Thus, the PTI induced by $P$. fluorescens PAMPs, particularly flagellin, appears sufficient to protect plant tissue against susceptibility to T3SS-dependent $\mathrm{HR}$ elicitation. $\mathrm{HrpH}_{\mathrm{PtoDC} 3000}$ and $\mathrm{HrpP}_{\mathrm{PtoDC} 3000}$ are clearly able to suppress that basal PTI as well as any additional defenses induced by the pLN18-encoded T3SS.

A new concept emerging from studies primarily involving animal pathogens is that hosts discriminate pathogens from nonpathogens by patterns of pathogenesis (Vance et al. 2009). Such patterns could include presentation of PAMPs in a manner characteristic of pathogens or indicators that a microbe has access to the host cytosol. A functional T3SS could be involved in both types of signaling, for example, by permitting PAMPs such as peptidoglycan fragments and flagellin to be delivered into host cells or by creating pores in the host plasma membrane that are sensed through ion fluxes or damage products (Lightfield et al. 2008; Shin and Cornelis 2007; Sun et al. 2007; Vance et al. 2009). As described above, a substantial toolkit has been assembled for further exploring the basis for plant ROS elicitation by the $P$. syringae pv. syringae 61 T3SS functioning in $P$. fluorescens, and ongoing progress in deleting all active effector genes from DC3000 promises to provide a test for this phenomenon in a native $P$. syringae background. In summary, just as many effectors have been shown to function as double agents in both eliciting and suppressing plant defenses, our data indicate that the T3SS itself also has this property.

\section{MATERIALS AND METHODS}

\section{Bacterial strains and plasmids.}

Bacterial strains and plasmids used in this study are listed in Table 1. Escherichia coli strains were grown in Luria-Bertani (LB) broth at $37^{\circ} \mathrm{C}$. Strains of $P$. fluorescens $(\mathrm{pLN} 18$ and effector clones) and $P$. syringae pv. tomato DC3000 cultures were grown on King's B (KB) medium (King et al. 1954) at $28^{\circ} \mathrm{C}$. E. coli DH5 $\alpha$ was used for general cloning procedure. Additionally, $E$. coli TOP10 and DB3.1 cells were used for deletion in pHIR11 and propagation of pCPP3214 containing the lethal $c c d B$ gene. Antibiotics were used at the following concentrations $\left(\mu \mathrm{g} \mathrm{ml}^{-1}\right)$ : kanamycin, 50; gentamicin, 40; tetracycline, 10; streptomycin, 100; ampicillin, 100; and rifampicin, 50. For marker exchange, gentamicin and kanamycin were used at half concentration.

\section{DNA manipulations.}

Plasmid DNA was isolated and manipulated using standard methods (Sambrook and Russel 2001). All constructs were created by polymerase chain reaction (PCR) using ExTaq polymerase (Takara Bio, Inc. Otsu, Shiga, Japan) and specific primers for each effector and the genomic DNA of $P$. syringae pv. tomato DC3000 as a template (Table 2). The PCR products were cloned into a pENTR/SD-TOPO vector (Invitrogen, Carlsbad, CA, U.S.A.) and were sequenced at the Cornell BioResource Center (Ithaca, NY, U.S.A.) with an ABI 3700 DNA analyzer. Entry clones were transferred into appropriate destination vectors, as indicated in Table 1 . Each resulting construct was conjugated into $P$. syringae or $P$. fluorescens strains by triparental mating, using pRK2013.

\section{Construction of pCPP6209, pCPP6211, and pCPP6212.}

In order to make $\triangle h o p A 1_{P s y 61}$ derivatives of pHIR11, pCPP5703, and pCPP2274, a 704-bp fragment carrying the left flanking region and a 954-bp fragment carrying the right flanking region of hopA $1_{P s y 6 l}$ were amplified by PCR using primer

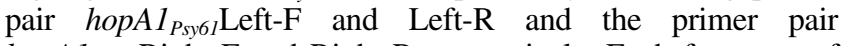

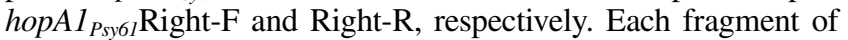
left and right regions was ligated at the $K p n I$ site and was then cloned into the HindIII and XbaI sites of pBluescript II SK(+) (Agilent Technologies, Inc., Santa Clara, CA, U.S.A.), using terminal primer-introduced restriction sites. pBluescript II SK(+) harboring left and right flanking regions of hopA $1_{P s y 6 l}$ was electro-transformed into $E$. coli $\mathrm{C} 2110$ carrying pHIR11 (Gopalan et al. 1996), pCPP5703, and pCPP2274 to produce pHIR11 hopA $1_{P s y 61}$, pCPP6209, and pCPP6211, respectively. Transformants were plated on LB agar medium supplemented with ampicillin and tetracycline at three times the normal level and incubated at $42^{\circ} \mathrm{C}$. Integrant strains were cured of pBluescript II $\mathrm{SK}(+)$ by incubation at $30^{\circ} \mathrm{C}$ and daily $1: 400$ subinoclations over 4 days, and then, were plated on LB agar medium supplemented with $30 \mu \mathrm{g}$ of tetracycline per milliliter. Recovered single colonies were screened for ampicillin sensitivity and were analyzed by colony PCR to confirm the deletion of hopA $1_{P_{s y 61} \text {. }}$.

To create a $\Delta h r p K 1_{P_{s y 6 l}}$ derivative of pHIR11 $h o p A 1_{P s y 61}$, 1,319- and 1,226-bp fragments of left and right regions of $h r p K 1_{P_{s y 6 l}}$ were PCR amplified, using primer pairs

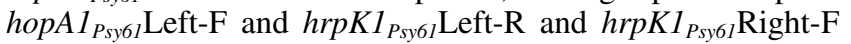
and Right-R, respectively, and were cloned into pBluescript II SK (+) and used for mutagenesis with E. coli C2110 carrying pHIR11 1 hopA $1_{P s y 61}$, as described above to produce pCPP6212.

To transfer pCPP6209, pCPP6211, and pCPP6212 into $P$. fluorescens 55, tri-parental mating was performed with pRK2013 as a helper. All transconjugants were confirmed by colony PCR using hopA $1_{P s y 61}$ and $h r p K 1_{P s y 61}$ primer pairs. Additionally, colony PCR was repeatedly conducted with a $h r p B$ primer pair to confirm maintenance of intact derivatives of 
pHIR11. All $P$. fluorescens 55 strains harboring pHIR11 derivative lacking $h o p A 1_{P_{s y 61}}$ or $h r p K 1_{P s y 61}$ were maintained at room temperature during experiments.

\section{Plant growth and bacterial inoculations.}

Fully expanded leaves from 6-week-old $N$. benthamiana plants were used for assays. Plants were grown under greenhouse conditions and were transferred to the laboratory one day before inoculation. The tested plants were maintained in the laboratory with a light intensity of $40 \mu \mathrm{mol} \mathrm{m} \mathrm{m}^{-2} \mathrm{~s}^{-1}$ at $25^{\circ} \mathrm{C}$. To infiltrate $P$. fluorescens (pLN18 and effector clones) strains into plants, bacteria cells were first grown on $\mathrm{KB}$ plates at $28^{\circ} \mathrm{C}$ overnight, then scraped from the agar, and resuspended in $5 \mathrm{mM}$ MES ( $\mathrm{pH} \mathrm{5.5)}$ at $2 \times 10^{8} \mathrm{CFU} \mathrm{ml}^{-1}$. To induce the expression of effectors, each bacterial suspension was supplemented with $200 \mu \mathrm{M}$ IPTG. For inoculation of DC3000, bacteria were grown on a $\mathrm{KB}$ plate at $28^{\circ} \mathrm{C}$ overnight and were resuspended in $10 \mathrm{mM} \mathrm{MgCl}{ }_{2}$. Bacterial infiltration was performed with a blunt syringe.

\section{Challenge-inoculation Cya translocation reporter assays.}

Strains of $P$. fluorescens(pLN18) expressing different T3SS substrates and a negative control strain were infiltrated at equi- distant spots on 6-week-old fully expanded leaves of $N$. benthamiana plants. The area of infiltration was marked with a felt-tipped pen to ensure that the second challenge inoculation overlapped the pretreated area. Each leaf had at least one nega-

Table 2. Primers used to construct and analyze mutations

\begin{tabular}{|c|c|c|}
\hline Primers & Sequences $5^{\prime}$ to $-3^{\prime}$ & Sites $^{\mathrm{a}}$ \\
\hline$h o p A 1_{P s y 61}$ Left-F & $\begin{array}{l}\text { TAATAAGCTTGATCCAATCCACGC } \\
\text { TCT }\end{array}$ & HindIII \\
\hline hopA $1_{P s y 61}$ Left-R & $\begin{array}{l}\text { TAATGGTACCTAAAAGCTCCTTAC } \\
\text { GCTA }\end{array}$ & KpnI \\
\hline hopA1 $1_{P s y 6 l}$ Right-F & $\begin{array}{l}\text { TAATGGTACCAATCGGGGCTAAA } \\
\text { TAGCT }\end{array}$ & KpnI \\
\hline hopA1 $1_{P s y 6 l}$ Right-R & $\begin{array}{l}\text { TAATTCTAGAATCGACAGCTCCAG } \\
\text { GTTG }\end{array}$ & XbaI \\
\hline$h r p K 1_{P s y 61}$ Left-R & $\begin{array}{l}\text { TAATGGTACCTAGCAGGGAAGAG } \\
\text { GTTGA }\end{array}$ & KpnI \\
\hline$h r p K 1_{P s y 61}$ Right-F & $\begin{array}{l}\text { TAATGGTACCGACAGATAACCAC } \\
\text { TCAGG }\end{array}$ & KpnI \\
\hline$h r p K 1_{P s y 61}$ Right-R & $\begin{array}{l}\text { TAATTCTAGACCATCGTCTTCTGC } \\
\text { CTGT }\end{array}$ & $X b a \mathrm{I}$ \\
\hline hopA1 $1_{\text {PtoDC300o }}-\mathrm{F}$ & CACCATGAACCCCATTCAGT & $\ldots$ \\
\hline hopA1 $1_{P t o D C 3000}-\mathrm{R}$ & GCATTTCGTGTTTCGAAGG & \\
\hline
\end{tabular}

${ }^{a}$ Restriction sites.

Table 1. Strains and plasmids used in this study

\begin{tabular}{|c|c|c|}
\hline Strain or plasmid & Relevant characteristics $^{\text {a }}$ & Source or reference \\
\hline Escherichia coli $\mathrm{DH} 5 \alpha$ & SupE44 $\triangle$ lacU169 (f80 lacZ4M15) hsdR17 recA1 endA1, gyrA96 thi-1 relA1 & $\begin{array}{l}\text { Life Technologies, } \\
\text { Gaithersburg, MD, U.S.A. }\end{array}$ \\
\hline TOP10 & $\begin{array}{l}\left.F^{-} \text {mcrA } \Delta m r r-h s d R M S-m c r B C\right) \phi 80 l a c Z \Delta M 15 \text { AlacX74 deoR recA1 araD139 } 4 \text { (ara- } \\
\text { leu)7679 galU galK rpsL endA1 nup }\end{array}$ & $\begin{array}{l}\text { Invitrogen, } \\
\text { Carlsbad, CA, U.S.A. }\end{array}$ \\
\hline DB3.1 & 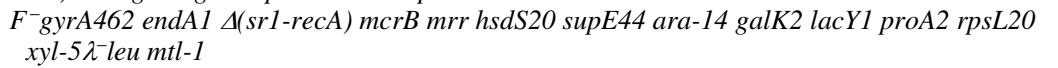 & Invitrogen \\
\hline BL21(DE3) & $F^{-}$ompT hsd $S_{B}\left(r_{B}^{-} m_{B}^{-}\right)$gal dcm $(D E 3)$ & Invitrogen \\
\hline Pseudomonas fluorescens 55 & Wild type, $\mathrm{Nx}^{\mathrm{r}}$ & Huang et al. 1988 \\
\hline P. syringae pv. tomato DC3000 & Wild type, Rif ${ }^{\mathrm{r}}$ & Cuppels 1986 \\
\hline \multicolumn{3}{|l|}{ Plasmids } \\
\hline pENTR/SD-TOPO & Entry vector of Gateway cloning, $\mathrm{Km}^{\mathrm{r}} \mathrm{Cm}^{\mathrm{r}}$ & Invitrogen \\
\hline pET-DEST42 & $\begin{array}{l}\text { pET Gateway compatible vector allowing for T7-regulated expression of a protein with a C- } \\
\text { terminal } \mathrm{His}_{6}-\mathrm{V} 5 \text { tag; Amp }\end{array}$ & Invitrogen \\
\hline pRK2013 & Helper plasmid; ColE1 replicon TraRK ${ }^{+} \mathrm{Mob}^{+} ; \mathrm{Km}^{\mathrm{r}}$ & Figurski and Helinski 1979 \\
\hline pHIR11 & pLAFR3 containing a 25-kb P. syringae pv. syringae 61 hrc-hrp gene cluster & Huang et al. 1988 \\
\hline pLN18 & pHIR 11 derivative with $s h c A$ and hopA 1 replaced by an $n p t I I$ cassette; $\mathrm{Tc}^{\mathrm{r}} \mathrm{Km}^{\mathrm{r}}$ & Jamir et al. 2004 \\
\hline pCPP2078 & pHIR 11 containing $h r c V:: \operatorname{Tn} p h o A ; \mathrm{Tc}^{\mathrm{r}}, \mathrm{Km}^{\mathrm{r}}$ & Huang et al. 1991 \\
\hline pCPP2274 & pHIR11 containing an unmarked deletion $h r p Z 1 ; \mathrm{Tc}^{\mathrm{r}}$ & Gopalan et al. 1996 \\
\hline pCPP3069 & $\begin{array}{l}\text { pCPP45 carrying a red-shift } g f p(\mathrm{~S} 65 \mathrm{~T}) \text { driven by a trp promoter (1.1-kb PstI-KpnI fragment } \\
\text { subcloned from pTB93F); } \mathrm{Tc}^{\mathrm{r}}\end{array}$ & W.-L. Deng \\
\hline pCPP3214 & pCPP3234 containing codons 2 to 406 of $c y a, \mathrm{Sp}^{\mathrm{r}} / \mathrm{Sm}^{\mathrm{r}}$; used as empty vector control & Schechter et al. 2004 \\
\hline pCPP3221 & pCPP3234 expressing AvrPto-Cya; $\mathrm{Sp} / \mathrm{Sm}^{\mathrm{r}}$ & Schechter et al. 2004 \\
\hline pCPP3234 & pVLT35 containing Gateway reading frame B cassette and codons 2 to 406 of cya; $\mathrm{Sp}^{\mathrm{r}} / \mathrm{Sm}^{\mathrm{r}} \mathrm{Cm}^{\mathrm{r}}$ & Schechter et al. 2004 \\
\hline pCPP3256 & pCPP3234 expressing HopP1 $1_{\text {PtoDC3000 }}-\mathrm{Cya} ; \mathrm{Sp}^{\mathrm{r}} / \mathrm{Sm}^{\mathrm{r}}$ & Kvitko et al. 2007 \\
\hline pCPP3258 & pCPP3234 expressing HrpW1-Cya; $\mathrm{Sp}^{\mathrm{r}} / \mathrm{Sm}^{\mathrm{r}}$ & Kvitko et al. 2007 \\
\hline pCPP3297 & pLN18 containing an unmarked $h r c C$ deletion; $\mathrm{Tc}^{\mathrm{r}}$ & Schechter et al. 2004 \\
\hline pCPP3489 & pCPP3234 carrying avrPto-stop-cya; $\mathrm{Sp}^{\mathrm{r}} / \mathrm{Sm}^{\mathrm{r}}$ & Oh et al. 2007 \\
\hline pCPP5154 & pENTR/SD-TOPO containing avrPto $; \mathrm{Km}^{\mathrm{r}}$ & Munkvold et al. 2008 \\
\hline pCPP5316 & pHIR 11 containing hopAl-cya translational fusion; $\mathrm{Tc}^{\mathrm{r}}$ & Oh et al. 2007 \\
\hline pCPP5708 & pCPP3234 expressing $\mathrm{HrpH}_{\mathrm{PtoDC} 3000}-\mathrm{Cya} ; \mathrm{Sp}^{\mathrm{r}} / \mathrm{Sm}^{\mathrm{r}}$ & Oh et al. 2007 \\
\hline pCPP5712 & pCPP3234 carrying hrpH $H_{P t o D C 3000^{-s t o p}-c y a ;} \mathrm{Sp}^{\mathrm{r}} / \mathrm{Sm}^{\mathrm{r}}$ & Oh et al. 2007 \\
\hline pCPP5713 & 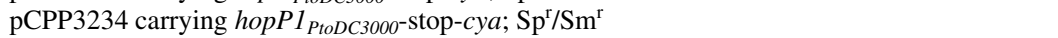 & Oh et al. 2007 \\
\hline pCPP5721 & pENTR/SD-TOPO containing $h r p H_{P t o D C 3000} ; \mathrm{Km}^{\mathrm{r}}$ & Oh et al. 2007 \\
\hline pCPP5725 & pET-DEST42 expressing $\mathrm{HrpH}_{\mathrm{PtoDC} 3000} ; \mathrm{Amp}^{\mathrm{r}}$ & Oh et al. 2007 \\
\hline pCPP5743 & pENTR/SD-TOPO containing hopP1 $1_{\text {PtoDC300o }} ; \mathrm{Km}^{\mathrm{r}}$ & Kvitko et al. 2007 \\
\hline pCPP5789 & pENTR/SD-TOPO containing $h r p H_{P t o D C 3000^{-}}$stop; $\mathrm{Km}^{\mathrm{r}}$ & Oh et al. 2007 \\
\hline pCPP5790 & pENTR/SD-TOPO containing hopP $1_{P t o D C 3000^{-s t o p} ; \mathrm{Km}^{\mathrm{r}}}$ & Oh et al. 2007 \\
\hline pCPP5792 & pENTR/SD-TOPO containing avrPto-stop; $\mathrm{Km}^{\mathrm{r}}$ & Oh et al. 2007 \\
\hline pCPP5871 & pET-DEST42 expressing HrpH $\mathrm{H}_{\mathrm{Psy} 61} ; \mathrm{Amp}^{\mathrm{r}}$ & Oh et al. 2007 \\
\hline pCPP6207 & pCPP3234 expressing $\mathrm{HrpH}_{\mathrm{Psy61}}-\mathrm{Cya} ; \mathrm{Sp}^{\mathrm{r}} / \mathrm{Sm}^{\mathrm{r}}$ & This study \\
\hline pCPP6208 & 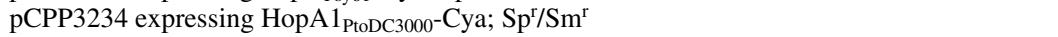 & This study \\
\hline pCPP6209 & pCPP5703 (pCPP5316 $\Delta h r p H:: F R T G m^{r}$ ) containing an unmarked deletion of hopA1 ${ }_{P s y 61} ;$ Tc $^{\mathrm{r}}$ & This work \\
\hline pCPP6211 & pCPP2274 containing an unmarked deletion of hopA1 $1_{P s y 61} ; \mathrm{Tc}^{\mathrm{r}}$ & This work \\
\hline pCPP6212 & pHIR11 containing unmarked deletions of hopA1 $1_{P s y 61}$ and $h r p K 1_{P s y 6 l} ; \mathrm{Tc}^{\mathrm{r}}$ & This work \\
\hline
\end{tabular}

${ }^{\mathrm{a}} \mathrm{Nx}^{\mathrm{r}}, \mathrm{Rif}^{\mathrm{r}}, \mathrm{Km}^{\mathrm{r}}, \mathrm{Cm}^{\mathrm{r}}, \mathrm{Tc}^{\mathrm{r}}, \mathrm{Sp}^{\mathrm{r}}, \mathrm{Sm}^{\mathrm{r}}$, and $\mathrm{Amp}^{\mathrm{r}}$ indicate resistance to nalidixic acid, rifampicin, kanamycin, chloramphenicol, tetracycline, spectinomycin, streptomycin, and ampicillin, respectively. 
tive control. The treated plants were maintained at $25^{\circ} \mathrm{C}$ under illumination for $6 \mathrm{~h}$. Translocation assays were performed as described previously (Schechter et al. 2004). Bacterial strains carrying plasmids expressing Cya fusions were infiltrated into $N$. benthamiana at $1 \times 10^{8} \mathrm{CFU} \mathrm{ml}{ }^{-1}$. Leaf disks were collected $6 \mathrm{~h}$ after infiltration with $1.0-\mathrm{cm}$-diameter cork border and were ground in $250 \mu \mathrm{l}$ of $0.1 \mathrm{M} \mathrm{HCl}$ in a $1.5-\mathrm{ml}$ microfuge tube using a plastic pestle driven by a Dremel tool. The cyclic AMP (cAMP) levels were determined using the Correlate-EIA cAMP immunoassay kit according to the manufacture's instructions (Assay Designs Inc, Ann Arbor, MI, U.S.A.)

\section{Challenge-inoculation HR assays.}

To test the ability of T3SS substrates heterologously expressed in $P$. fluorescens(pLN18) to suppress PTI based on the associated inhibition of the HR and electrolyte leakage, $P$. syringae pv. tomato DC3000 was challenge-inoculated $6 \mathrm{~h}$ later at $2 \times 10^{-7} \mathrm{CFU} \mathrm{ml}{ }^{-1}$, so as to partially overlap with the pretreated area. After $24 \mathrm{~h}$, leaves were photographed using a Nikon E-995 digital camera.

Challenge-inoculation bacterial colony development assay.

To observe the suppression of PTI-associated inhibition of the growth of pathogen challenge inoculation, $P$. syringae pv. tomato DC3000 was transformed with pCPP3069, which expresses green fluorescent protein (GFP) from a vector trp promoter. At $6 \mathrm{~h}$ after infiltration of $P$. fluorescens (pLN18) cells expressing different effectors or carrying empty vector, suspensions of GFP-expressing strains in $10 \mathrm{mM} \mathrm{MgCl}_{2}$ at $2 \times$ $10^{7} \mathrm{CFU} \mathrm{ml}{ }^{-1}$ were challenge-inoculated on the edge of the preinfiltrated area so as to produce an overlapped area and a nonoverlapped area. At $6 \mathrm{~h}$ after challenge, which is prior to the start of macroscopic necrosis, leaf strips were cut with a razor to include both inoculation areas. The development of bacterial colonies was observed using the $16 \times$ objective of a Bio-Rad MRC600 (Bio-Rad Laboratories, Hercules, CA, U.S.A.) confocal laser-scanning microscope.

\section{Vascular dye-accumulation assay.}

P. fluorescens(pLN18) cells expressing different effectors or carrying empty vector at $2 \times 10^{8} \mathrm{CFU} \mathrm{m}{ }^{-1}$ were infiltrated at four spots on 6-week-old fully expanded upper leaves of $N$. benthamiana plants. Each leaf was detached with a razor at the base of the petiole, and the petiole was directly placed in a $1 \%$ (wt/vol) neutral red water solution for $12 \mathrm{~h}$. Images were obtained using a Nikon E-995 digital camera.

To quantify the relative amount of transported neutral red dye in each treated area, leaf disks were collected with a 0.5 $\mathrm{cm}$-diameter cork borer from each inoculated area. Leaf disks were placed separately in wells of a 96-well microtiter plate with $200 \mu \mathrm{l}$ of $100 \%$ ethanol. Each well of the plate was tightly sealed with Parafilm to prevent any evaporation of solution, and the samples were incubated at room temperature for $1 \mathrm{~h}$ on a plate shaker at $200 \mathrm{rpm}$. To measure relative levels of dye extracted from each sample, $50 \mu \mathrm{l}$ of extracted ethanol solution from each well was diluted with $150 \mu \mathrm{l}$ of $5 \mathrm{mM}$ MES ( $\mathrm{pH}$ 5.5). The absorbance of each well was read at $562 \mathrm{~nm}$, using a MicroStation Reader (Biolog, Hayward, CA, U.S.A.). The experiment was repeated three times with similar results.

\section{Callose-deposition assay.}

$P$. fluorescens(pLN18) strains expressing different effectors were infiltrated into 5 -week-old $N$. benthamiana leaves at $2 \times$ $10^{8} \mathrm{CFU} \mathrm{ml} \mathrm{m}^{-1}$. At $24 \mathrm{~h}$ postinoculation, leaf disks of $N$. benthamiana samples measuring $1.0 \mathrm{~cm}$ in diameter were collected. The collected leaves were cleared by being separately placed in a six-well plate containing $2 \mathrm{ml}$ of $95 \%$ ethanol. The sam- ples were incubated at $37^{\circ} \mathrm{C}$ until the leaf was cleared of chlorophyll. Cleared leaves were rinsed twice with $70 \%$ ethanol and, then, twice with water. The leaf disks were immersed in $150 \mathrm{mM} \mathrm{K}_{2} \mathrm{HPO}_{4}(\mathrm{pH} 9.5$ ) containing $0.1 \%$ aniline blue for 2 $\mathrm{h}$ in the dark. The stained samples were washed with distilled water and were mounted in $60 \%$ glycerol. Callose was observed by epifluorescence microscopy with an Olympus BX60F microscope and MNU filter tube (360 to $370 \mathrm{nM}$ excitation filter, DM400 dichroic mirror, and BA420 long-pass filter; Olympus, Tokyo).

\section{ROS assay.}

For ROS measurements, $P$. fluorescens (pLN18) strains expressing different effectors and a negative control $(10 \mathrm{mM}$ $\mathrm{MgCl}_{2}$ ) were infiltrated into 5-week-old $N$. benthamiana leaves at $2 \times 10^{8} \mathrm{CFU} \mathrm{ml}{ }^{-1}$. At $15 \mathrm{~h}$ postinoculation, leaf disks $(0.5$ $\mathrm{cm}$ in diameter) were excised and placed into wells of 96-well plates, and then, $100 \mu \mathrm{l}$ of $0.5 \mathrm{mM} \mathrm{L-012} \mathrm{(Wako,} \mathrm{Kyoto,} \mathrm{Japan)}$ in $10 \mathrm{mM}$ morpholinepropanesulfonic acid morpholinepropanesulfonic acid-KOH buffer ( $\mathrm{pH}$ 7.4) was added. The intensity of ROS generation was determined by counting photons from L-012-mediated chemiluminescence as previously described (Asai et al. 2008). Chemiluminescence was monitored using a Veritas luminometer (Promega, Fitchburg, WI, U.S.A.) and was quantified by the BrightGlo Promega program.

\section{Immunoblot analysis.}

Protein samples were separated by electrophoresis on sodium dodecyl sulfate-polyacrylamide gel electrophoresis gels and were transferred to Immobilon-P membranes (Millipore, Billerica, MA, U.S.A.) by using a Semiphor semidry transfer system (Hoefer, Holliston, MA, U.S.A.). Immunoblot analysis was carried out by using a Western-Light Plus kit (Applied Biosystems, Bedford, MA, U.S.A.) according to the manufacturer's instructions. Cya fusion proteins were detected by using primary anti-Cya (3D1) mouse monoclonal immunoglobulin G (IgG) antibodies (Santa Cruz Biotechnology, Santa Cruz, CA, U.S.A.) at a dilution of 1:5,000 and secondary anti-mouse IgGalkaline phosphatase conjugate antibodies (Sigma-Aldrich, St. Louis) at a dilution of 1:30,000.

\section{Bacterial toxicity assay.}

E. coli BL21(DE3) harboring native $h_{r p H} H_{P s y 61}$ or $h r p H_{P t o D C 3000}$ expressed from pET-DEST42 were grown in 5 $\mathrm{ml}$ of LB broth supplemented with ampicillin at $37^{\circ} \mathrm{C}$ overnight, inoculated to new media, and allowed to grow until the optical density at $600 \mathrm{~nm}\left(\mathrm{OD}_{600}\right)$ had reached 0.10 . The $\mathrm{T} 7 /$ lacO promoter of the vector, driving expression of the test proteins, was activated by addition of $0.5 \mathrm{mM}$ IPTG, and the $\mathrm{OD}_{600}$ was further monitored. The experiment was repeated three times with similar results.

\section{ACKNOWLEDGMENTS}

We thank K. E. Loeffler for photography, C.-S. Oh for guidance with the ROS assays, W.-L. Deng for construction of pCPP3069, and G. Hooker for statistical analysis. This work was supported by National Science Foundation grants MCB-0544066 and DBI-0605059.

\section{LITERATURE CITED}

Alfano, J. R., Kim, H.-S., Delaney, T. P., and Collmer, A. 1997. Evidence that the Pseudomonas syringae pv. syringae hrp-linked hrmA gene encodes an Avr-like protein that acts in a hrp-dependent manner within tobacco cells. Mol. Plant-Microbe Interact. 10:580-588.

Almeida, N. F., Yan, S., Lindeberg, M., Studholme, D. J., Schneider, D. J., Condon, B., Liu, H., Viana, C. J., Warren, A., Evans, C., Kemen, E., MacLean, D., Angot, A., Martin, G. B., Jones, J. D., Collmer, A., 
Setubal, J. C., and Vinatzer, B. A. 2009. A draft genome sequence of Pseudomonas syringae pv. tomato strain T1 reveals a repertoire of Type III related genes significantly divergent from that of Pseudomonas syringae pv tomato strain DC3000. Mol. Plant-Microbe Interact. 22:5262.

Asai, S., Ohta, K., and Yoshioka, H. 2008. MAPK signaling regulates nitric oxide and NADPH oxidase-dependent oxidative bursts in Nicotiana benthamiana. Plant Cell 20:1390-1406.

Blocker, A. J., Deane, J. E., Veenendaal, A. K., Roversi, P., Hodgkinson, J. L., Johnson, S., and Lea, S. M. 2008. What's the point of the type III secretion system needle? Proc. Natl. Acad. Sci. U.S.A. 105:6507-6513.

Boch, J., Joardar, V., Gao, L., Robertson, T. L., Lim, M., and Kunkel, B. N. 2002. Identification of Pseudomonas syringae genes induced during infection of Arabidopsis thaliana. Mol. Microbiol. 44:73-88.

Boller, T., and Felix, G. 2009. A renaissance of elicitors: Perception of microbe-associated molecular patterns and danger signals by pattern-recognition receptors. Annu. Rev. Plant Biol. 60:379-406.

Casper-Lindley, C., Dahlbeck, D., Clark, E. T., and Staskawicz, B. J. 2002. Direct biochemical evidence for type III secretion-dependent translocation of the AvrBs2 effector protein into plant cells. Proc. Natl. Acad. Sci. U.S.A. 99:8336-8341.

Chakravarthy, S., Velásquez, A. C., Ekengren, S. K., Collmer, A., and Martin, G. B. 2010. Identification of Nicotiana benthamiana genes involved in PAMP-triggered immunity. Mol. Plant-Microbe Interact. 23:715-726.

Chang, J. H., Urbach, J. M., Law, T. F., Arnold, L. W., Hu, A., Gombar, S., Grant, S. R., Ausubel, F. M., and Dangl, J. L. 2005. A high-throughput, near-saturating screen for type III effector genes from Pseudomonas syringae. Proc. Natl. Acad. Sci. U.S.A. 102:2549-2554

Charkowski, A. O., Huang, H.-C., and Collmer, A. 1997. Altered localization of HrpZ in Pseudomonas syringae pv. syringae hrp mutants suggests that different components of the type III secretion pathway control protein translocation across the inner and outer membranes of gramnegative bacteria. J. Bacteriol. 179:3866-3874.

Charkowski, A. O., Alfano, J. R., Preston, G., Yuan, J., He, S. Y., and Collmer, A. 1998. The Pseudomonas syringae pv. tomato HrpW protein has domains similar to harpins and pectate lyases and can elicit the plant hypersensitive response and bind to pectate. J. Bacteriol. 180:5211-5217.

Chinchilla, D., Zipfel, C., Robatzek, S., Kemmerling, B., Nurnberger, T., Jones, J. D., Felix, G., and Boller, T. 2007. A flagellin-induced complex of the receptor FLS2 and BAK1 initiates plant defence. Nature $448: 497-500$

Cunnac, S., Lindeberg, M., and Collmer, A. 2009. Pseudomonas syringae type III secretion system effectors: Repertoires in search of functions. Curr. Opin. Microbiol. 12:53-60.

Cuppels, D. A. 1986. Generation and characterization of Tn5 insertion mutations in Pseudomonas syringae pv. tomato. Appl. Environ. Microbiol. 51:323-327.

Figurski, D., and Helinski, D. R. 1979. Replication of an origin-containing derivative of plasmid RK2 dependent on a plasmid function provided in trans. Proc. Natl. Acad. Sci. U.S.A. 76:1648-1652.

Fouts, D. E., Abramovitch, R. B., Alfano, J. R., Baldo, A. M., Buell, C. R., Cartinhour, S., Chatterjee, A. K., D'Ascenzo, M., Gwinn, M. L., Lazarowitz, S. G., Lin, N.-C., Martin, G. B., Rehm, A. H., Schneider, D. J., van Dijk, K., Tang, X., and Collmer, A. 2002. Genomewide identification of Pseudomonas syringae pv. tomato DC3000 promoters controlled by the HrpL alternative sigma factor. Proc. Natl. Acad. Sci. U.S.A. 99:2275-2280

Freeman, B. C., and Beattie, G. A. 2009. Bacterial growth restriction during host resistance to Pseudomonas syringae is associated with leaf water loss and localized cessation of vascular activity in Arabidopsis thaliana. Mol. Plant-Microbe Interact. 22:857-867.

Gopalan, S., Bauer, D. W., Alfano, J. R., Loniello, A. O., He, S. Y., and Collmer, A. 1996. Expression of the Pseudomonas syringae avirulence protein AvrB in plant cells alleviates its dependence on the hypersensitive response and pathogenicity (Hrp) secretion system in eliciting genotype-specific hypersensitive cell death. Plant Cell 8:1095-1105.

Guo, M., Tian, F., Wamboldt, Y., and Alfano, J. R. 2009. The majority of the type III effector inventory of Pseudomonas syringae pv. tomato DC3000 can suppress plant immunity. Mol. Plant-Microbe Interact. 22:1069-1080.

Gust, A. A., Biswas, R., Lenz, H. D., Rauhut, T., Ranf, S., Kemmerling, B., Gotz, F., Glawischnig, E., Lee, J., Felix, G., and Nurnberger, T 2007. Bacteria-derived peptidoglycans constitute pathogen-associated molecular patterns triggering innate immunity in Arabidopsis. J. Biol. Chem. 282:32338-32348.

Guttman, D. S., and Greenberg, J. T. 2001. Functional analysis of the type III effectors AvrRpt2 and AvrRpm1 of Pseudomonas syringae with the use of a single-copy genomic integration system. Mol. Plant-Microbe Interact. 14:145-155.
Hann, D. R., and Rathjen, J. P. 2007. Early events in the pathogenicity of Pseudomonas syringae on Nicotiana benthamiana. Plant J. 49:607-618.

Hauck, P., Thilmony, R., and He, S. Y. 2003. A Pseudomonas syringae type III effector suppresses cell wall-based extracellular defense in susceptible Arabidopsis plants. Proc. Natl. Acad. Sci. U.S.A. 100:85778582.

He, S. Y., Huang, H.-C., and Collmer, A. 1993. Pseudomonas syringae pv. syringae harpin ${ }_{\mathrm{Pss}}$ : A protein that is secreted via the Hrp pathway and elicits the hypersensitive response in plants. Cell 73:1255-1266.

Huang, H.-C., Hutcheson, S. W., and Collmer, A. 1991. Characterization of the hrp cluster from Pseudomonas syringae pv. syringae 61 and TnphoA tagging of genes encoding exported or membrane-spanning Hrp proteins. Mol. Plant-Microbe Interact. 4:469-476.

Huang, H.-C., Schuurink, R., Denny, T. P., Atkinson, M. M., Baker, C. J., Yucel, I., Hutcheson, S. W., and Collmer, A. 1988. Molecular cloning of a Pseudomonas syringae pv. syringae gene cluster that enables Pseudomonas fluorescens to elicit the hypersensitive response in tobacco plants. J. Bacteriol. 170:4748-4756.

Jamir, Y., Guo, M., Oh, H.-S., Petnicki-Ocwieja, T., Chen, S., Tang, X., Dickman, M. B., Collmer, A., and Alfano, J. R. 2004. Identification of Pseudomonas syringae type III secreted effectors that suppress programmed cell death in plants and yeast. Plant J. 37:554-565.

Jones, J. D., and Dangl, J. L. 2006. The plant immune system. Nature 444:323-329

King, E. O., Ward, M. K., and Raney, D. E. 1954. Two simple media for the demonstration of pyocyanin and fluorescin. J. Lab. Clin. Med. 44:301-307.

Klement, Z., Bozso, Z., Kecskes, M. L., Besenyei, E., Arnold, C., and Ott, P. G. 2003. Local early induced resistance of plants as the first line of defence against bacteria. Pest Manage. Sci. 59:465-474.

Koraimann, G. 2003. Lytic transglycosylases in macromolecular transport systems of Gram-negative bacteria. Cell Mol. Life Sci. 60:2371-2388.

Kvitko, B. H., Ramos, A. R., Morello, J. E., Oh, H.-S., and Collmer, A. 2007. Identification of harpins in Pseudomonas syringae pv. tomato DC3000, which are functionally similar to HrpK1 in promoting translocation of type III secretion system effectors. J. Bacteriol. 189:80598072

Kvitko, B. H., Park, D. H., Velásquez, A. C., Wei, C.-F., Russell, A. B., Martin, G. B., Schneider, D. J., and Collmer, A. 2009. Deletions in the repertoire of Pseudomonas syringae pv. tomato DC3000 type III secretion effector genes reveal functional overlap among effectors. PLoS Pathog. 5:e1000388.

Lightfield, K. L., Persson, J., Brubaker, S. W., Witte, C. E., von Moltke, J., Dunipace, E. A., Henry, T., Sun, Y. H., Cado, D., Dietrich, W. F., Monack, D. M., Tsolis, R. M., and Vance, R. E. 2008. Critical function for Naip5 in inflammasome activation by a conserved carboxy-terminal domain of flagellin. Nat. Immunol. 9:1171-1178.

Lindeberg, M., Stavrinides, J., Chang, J. H., Alfano, J. R., Collmer, A., Dangl, J. L., Greenberg, J. T., Mansfield, J. W., and Guttman, D. S. 2005. Proposed guidelines for a unified nomenclature and phylogenetic analysis of type III Hop effector proteins in the plant pathogen Pseudomonas syringae. Mol. Plant-Microbe Interact. 18:275-282.

Lindeberg, M., Cartinhour, S., Myers, C. R., Schechter, L. M., Schneider, D. J., and Collmer, A. 2006. Closing the circle on the discovery of genes encoding Hrp regulon members and type III secretion system effectors in the genomes of three model Pseudomonas syringae strains. Mol. Plant Microbe Interact. 19:1151-1158.

Mansfield, J., Jenner, C., Hockenhull, R., Bennett, M. A., and Stewart, R. 1994. Characterization of avrPphE, a gene for cultivar-specific avirulence from Pseudomonas syringae pv. phaseolicola which is physically linked to $h r p Y$, a new $h r p$ gene identified in the halo-blight bacterium. Mol. Plant-Microbe Interact. 7:726-739.

Melotto, M., Underwood, W., Koczan, J., Nomura, K., and He, S. Y. 2006. Plant stomata function in innate immunity against bacterial invasion. Cell 126:969-980.

Mudgett, M. B., and Staskawicz, B. J. 1999. Characterization of the Pseudomonas syringae pv. tomato AvrRpt2 protein: Demonstration of secretion and processing during bacterial pathogenesis. Mol. Microbiol. 32:927-941.

Munkvold, K. R., Martin, M. E., Bronstein, P. A., and Collmer, A. 2008. A survey of the Pseudomonas syringae pv. tomato DC3000 type III secretion system effector repertoire reveals several effectors that are deleterious when expressed in Saccharomyces cerevisiae. Mol. Plant-Microbe Interact. 21:490-502.

Oh, H.-S., and Collmer, A. 2005. Basal resistance against bacteria in Nicotiana benthamiana leaves is accompanied by reduced vascular staining and suppressed by multiple Pseudomonas syringae type III secretion system effector proteins. Plant J. 44:348-359.

Oh, H.-S., Kvitko, B. H., Morello, J. E., and Collmer, A. 2007. Pseudomonas syringae lytic transglycosylases co-regulated with the type III se- 
cretion system contribute to the translocation of effector proteins into plant cells. J. Bacteriol. 189:8277-8289.

Petnicki-Ocwiega, T., van Dijk, K., and Alfano, J. R. 2005. The hrpK operon of Pseudomonas syringae pv. tomato DC3000 encodes two proteins secreted by the type III (Hrp) protein secretion system: HopB1 and HrpK, a putative type III translocator. J. Bacteriol. 187:649-663.

Pirhonen, M. U., Lidell, M. C., Rowley, D. L., Lee, S. W., Jin, S., Liang, Y., Silverstone, S., Keen, N. T., and Hutcheson, S. W. 1996. Phenotypic expression of Pseudomonas syringae avr genes in E. coli is linked to the activities of the hrp-encoded secretion system. Mol. Plant-Microbe Interact. 9:252-260.

Preston, G., Huang, H.-C., He, S. Y., and Collmer, A. 1995. The HrpZ proteins of Pseudomonas syringae pvs. syringae, glycinea, and tomato are encoded by an operon containing Yersinia ysc homologs and elicit the hypersensitive response in tomato but not soybean. Mol. Plant-Microbe Interact. 8:717-732.

Ramos, A. R., Morello, J. E., Ravindran, S., Deng, W.-L., Huang, H.-C., and Collmer, A. 2007. Identification of Pseudomonas syringae pv. syringae 61 type III secretion system Hrp proteins that can travel the type III pathway and contribute to the translocation of effector proteins into plant cells. J. Bacteriol. 189:5773-5778.

Roine, E., Wei, W., Yuan, J., Nurmiaho-Lassila, E.-L., Kalkkinen, N., Romantschuk, M., and He, S. Y. 1997. Hrp pilus: An hrp-dependent bacterial surface appendage produced by Pseudomonas syringae pv. tomato DC3000. Proc. Natl. Acad. Sci. U.S.A. 94:3459-3464.

Sambrook, J., and Russel, D. W. 2001. Molecular Cloning: A Laboratory Manual. Cold Spring Harbor Laboratory Press, Cold Spring Harbor, NY, U.S.A.

Schechter, L. M., Roberts, K. A., Jamir, Y., Alfano, J. R., and Collmer, A. 2004. Pseudomonas syringae type III secretion system targeting signals and novel effectors studied with a Cya translocation reporter. J. Bacteriol. 186:543-555.

Shin, H., and Cornelis, G. R. 2007. Type III secretion translocation pores of Yersinia enterocolitica trigger maturation and release of pro-inflammatory IL-1b. Cell Microbiol 9:2893-2902.
Sory, M.-P., and Cornelis, G. R. 1994. Translocation of a hybrid YopE-adenylate cyclase from Yersinia enterocolitica into HeLa cells. Mol. Microbiol. 14:583-594.

Sun, Y. H., Rolan, H. G., and Tsolis, R. M. 2007. Injection of flagellin into the host cell cytosol by Salmonella enterica serotype Typhimurium. J Biol. Chem. 282:33897-33901.

Thomas, W. J., Thireault, C. A., Kimbrel, J. A., and Chang, J. H. 2009. Recombineering and stable integration of the Pseudomonas syringae pv. syringae $61 \mathrm{hrp} / \mathrm{hrc}$ cluster into the genome of the soil bacterium Pseudomonas fluorescens Pf0-1. Plant J. 60:919-928.

Torres, M. A., Jones, J. D., and Dangl, J. L. 2006. Reactive oxygen species signaling in response to pathogens. Plant Physiol. 141:373-378.

van Dijk, K., Tam, V. C., Records, A. R., Petnicki-Ocwieja, T., and Alfano, J. R. 2002. The ShcA protein is a molecular chaperone that assists in the secretion of the HopPsyA effector from the type III (Hrp) protein secretion system of Pseudomonas syringae. Mol. Microbiol. 44:1469-1481.

Vance, R. E., Isberg, R. R., and Portnoy, D. A. 2009. Patterns of pathogenesis: Discrimination of pathogenic and nonpathogenic microbes by the innate immune system. Cell Host Microbe 6:10-21.

Wei, C.-F., Kvitko, B. H., Shimizu, R., Crabill, E., Alfano, J. R., Lin, N.C., Martin, G. B., Huang, H.-C., and Collmer, A. 2007. A Pseudomonas syringae pv. tomato DC3000 mutant lacking the type III effector HopQ1-1 is able to cause disease in the model plant Nicotiana benthamiana. Plant J. 51:32-46.

Wei, W., Plovanich-Jones, A., Deng, W.-L., Collmer, A., Huang, H.-C. and He, S. Y. 2000. The gene coding for the Hrp pilus structural protein is required for type III secretion of Hrp and Avr proteins in Pseudomonas syringae pv. tomato. Proc. Natl. Acad. Sci. U.S.A. 97:2247-2252.

AUTHOR-RECOMMENDED INTERNET RESOURCE

Pseudomonas syringae genome resources home page: pseudomonas-syringae.org 